Atmos. Chem. Phys. Discuss., doi:10.5194/acp-2016-352, 2016

\title{
A long term study of polar ozone loss derived from data assimilation of Odin/SMR observations
}

\author{
Kazutoshi Sagi ${ }^{1}$ and Donal Murtagh ${ }^{1}$ \\ ${ }^{1}$ Department of Earth and Space Sciences, Chalmers University of Technology, Gothenburg, Sweden \\ Correspondence to: Kazutoshi Sagi \\ sagi@chalmers.se
}

\begin{abstract}
Odin, a Swedish-led satellite project in collaboration with Canada, France and Finland, was launched on 20 February 2001 and continues to produce profiles of chemical species relevant to understanding the middle and upper atmosphere. Longterm observations of stratospheric ozone are useful for trend analysis of chemical ozone loss. This study concerns ozone loss over both poles utilizing 12 years of ozone data from Odin/Sub-Millimetre Radiometer (SMR). We have applied the data assimilation technique described by Rösevall et al. (2007) with a number of improvements to study the inter-annual variability during the entire Odin period. The chemical ozone losses at potential temperature levels between $425 \mathrm{~K}$ and $950 \mathrm{~K}$
\end{abstract} , ( corresponding to an altitude range of 15 to $40 \mathrm{~km}$ approximately $90 \mathrm{hPa}$ and $7 \mathrm{hPa}$ in pressure), are derived.

Two SMR ozone products retrieved from the emission lines centred at $501 \mathrm{GHz}$ and $544 \mathrm{GHz}$ were used. An internal comparison of the two analyses using $501 \mathrm{GHz}$ and $544 \mathrm{GHz}$ ozone has been carried out by inspecting the vortex mean ozone in March and October during $2002-2013$ and 2003 - 2012 in the Northern and Southern Hemisphere, respectively. Ozone derived from data assimilation using the two data sets match within $10 \%$ at the levels studied, while below $550 \mathrm{~K}$ in the Southern Hemispheremore than $50 \%$ of the difference is found. Here, $544 \mathrm{GHz}$ ozone is 0.5 parts per million volume (ppmv) lower than $501 \mathrm{GHz}$ ozone because of better sensitivity in $544 \mathrm{GHz}$ ozone in the lower stratosphere. Comparisons with other studies have been mainly performed against Sonkaew et al. (2013) since Sonkaew et al. (2013) is one of the few studies having consistent estimations of ozone depletion using a SCanning Imaging Absorption SpectroMeter for Atmospheric CHartographY (SCIAMACHY) from 2002 to 2009. $544 \mathrm{GHz}$ ozone loss in the Arctic winter 2004/2005 is in good agreement with SCIAMACHY loss below $450 \mathrm{~K}$ to within $0.2 \mathrm{ppmv}$, while showing no loss around $550 \mathrm{~K}$ where SCIAMACHY detected 0.5 ppmv loss. The comparison of Antarctic ozone depletions with Kuttippurath et al. (2015) shows agreement with MLS ozone loss within 0.1 ppmv, while our results were constantly 0.3 ppmv lower than Mimosa-Chim model calculations.

In the Northern Hemisphere, our assimilation analyses show large inter-annual variability. Three classes of chemical ozone losses are found to occur in cold, warm and intermediate winters between cold and warm. The cold type loss maximises in March below $500 \mathrm{~K}$ as in the Southern Hemisphere. The maximum loss in the Northern Hemisphere between 2001/2002 and 2012/2013 was during the cold winter, which happened in 2010/2011 with a loss in volume mixing ratio of 2.1 ppmv at $450 \mathrm{~K}$. Losses of 1.5 ppmv took place at $700 \mathrm{~K}$ in the warm winters related to the occurrence of mid-winter major sudden stratospheric warming (SSW) events. In the Southern Hemisphere between 2002 and 2012, chemical ozone losses began in mid-August and generally grew to $2.5 \mathrm{ppmv}$ by the end of October. The vertical extent of this loss was $425-550 \mathrm{~K}$. All Antarctic winters except 
Atmos. Chem. Phys. Discuss., doi:10.5194/acp-2016-352, 2016

Atmospheric

Chemistry

Manuscript under review for journal Atmos. Chem. Phys.

Published: 30 June 2016

(c) Author(s) 2016. CC-BY 3.0 License.

and Physics

Discussions

(c) (i)

2002 had approximately 80 DU loss in the stratospheric column. In both hemispheres partial columns in the stratosphere show a small increase over the time period from 2002 to 2013 , however the statistical confidence is not high enough to identify ozone recovery.

\section{Introduction}

5 Ozone depletion and climate change are indirectly linked. Several studies have predicted that the stratospheric cooling induced by the increasing atmospheric carbon dioxide will enhance ozone depletion (Austin et al., 1992; Shindell et al., 1998). In practice, the Arctic lower stratosphere has been getting colder over the past decades (WMO, 2011). The linear dependence, demonstrated by (Rex et al., 2006), between the ozone depletion and the volume of air having temperature below the threshold for polar stratospheric cloud (PSC) formation implies that the stratospheric $\mathrm{O}_{3}$ depletion in Northern Hemisphere may become worse if the cooling trend continues. It is therefore important to have continuous observations and trend analyses of the ozone depletion.

Ozone loss has been quantified by using a variety of techniques based on different assumptions and instruments (e.g. Eichmann et al., 2002; Grooß and Müller, 2003; Rex et al., 2006; Singleton et al., 2007; Tilmes et al., 2004; Tsvetkova et al., 2007). However, most of the studies were done for individual winters in the last decade. For instance, in the Arctic winter 2010/2011 several groups reported the unprecedented dramatic ozone depletion over the Arctic polar region approaching that of the Antarctic ozone hole (e.g. Arnone et al., 2012; Manney et al., 2011; Sinnhuber et al., 2011). This winter was obviously different from other Arctic winters from 2000 since the polar vortex was strong and isolated the vortex air from the outside, the polar vortex was sustained by very cold temperatures. For this specific winter we have a number of publications to refer to, while few publications are available for other winters that do not show such dramatic events, i.e unusually cold weather in the lower stratosphere or sudden stratospheric warmings (SSW). One long term study of ozone loss was performed using the SCanning Imaging Absorption spectroMeter for Atmospheric CHartographY (SCIAMACHY) (Sonkaew et al., 2013). Sonkaew et al. (2013) estimated ozone loss between 2002 and 2009 and showed a quasi-biennial oscillation (QBO) effect in the inter-annual variability of their derived Arctic ozone losses.

The Odin satellite was built by Sweden in association with Canada, Finland and France as an observatory aimed at radio astronomy and limb sounding of the Earth's middle atmosphere (Murtagh et al., 2002). It carries two different limb sounding instruments, OSIRIS (Optical Spectrograph/ InfraRed Imaging System) and SMR (Sub-Millimetre Radiometer). Since launch in February 2001, Odin continues to provide data producing a relatively long record of stratospheric ozone. Rösevall et al. (2007, 2008) developed the DIAMOND (Dynamic Isentropic Assimilation Model for OdiN Data) model and estimated polar ozone loss in specific winters such as the Arctic 2002/2003 and Antarctic 2003, Arctic 2004/2005 and Arctic 2006/2007. Sagi et al. (2014) updated the DIAMOND model by adding and testing an explicit vertical transport scheme applying it to both Japanese Experiment Module (JEM) / Superconducting Submillimeter-Wave Limb Emission Sounder (SMILES) and Odin/SMR data to study the 2009/2010 Arctic winter. The subject of this paper is to summarize the ozone loss changes on a decadal time-scale by applying the data assimilation technique used in the previous studies to the entire Odin ozone observation period. Generally 
Atmos. Chem. Phys. Discuss., doi:10.5194/acp-2016-352, 2016

Atmospheric

Chemistry

Published: 30 June 2016

(c) Author(s) 2016. CC-BY 3.0 License.

$\frac{\text { and Physics }}{\text { Discussions }}$

(c) (i)

previous studies focused on ozone loss below a potential temperature (PT) of $600 \mathrm{~K}$ (approximately $24 \mathrm{hPa}$ in pressure and $30 \mathrm{~km}$ in altitudes) since the Antarctic ozone holes are mainly caused by chlorine chemistry following PSC formation. However Konopka et al. (2007) showed that,above $600 \mathrm{~K}(\sim 24 \mathrm{~km})$, the chemical loss induced by the horizontal transport of $\mathrm{NO}_{x}$ from lower latitudes is as great as the halogen-induced loss below $500 \mathrm{~K}(\sim 20 \mathrm{~km})$ in the Northern Hemisphere in 2002/2003.

5 In this paper we have extended the vertical analysis region up to PT of $950 \mathrm{~K}(\sim 40 \mathrm{~km})$ in order to show the effect of $\mathrm{NO}_{x}$ transport on ozone losses.

This paper contains the following sections. The methodology and the assimilation model that we used to determine chemical ozone change are described in section 2. Section 3 deals with the SMR instrument, whose stratospheric ozone observations are introduced into the model in this study. Section 4.1 discusses the determination of the polar vortex edge in both hemispheres during polar winter and spring. Section 4.2 present an internal comparison between ozone losses derived from two different SMR ozone measurements, while section 4.3 shows the comparison with other studies. Next we look at the inter-annual variation of ozone loss averaged over the Arctic and Antarctic winters in Sect. 4.4.1 and Sect. 4.4.2, respectively. In section 4.4.3 we have an additional discussion of inter-annual variations in both hemispheres of the lower-stratospheric partial column. Conclusions are presented in the last section.

\section{Methodology}

Stratospheric ozone observed by the SMR instrument is affected by not only chemical process but also transport. Thus the unstable nature of the Arctic vortex due to the propagation of planetary waves excited by the complex topography of Northern Hemisphere makes quantifying chemical $\mathrm{O}_{3}$ loss in the Arctic more difficult. Therefore it is necessary to find a suitable method for extracting the contribution of chemical change in ozone. Using a transport model can help to separate the two processes, i.e. transport and chemistry, but we need to ensure that ozone is treated in a consistent manner. Data assimilation is a process by which observations are introduced into a model while constraining these to follow model physics (Lahoz et al., 2010) . We have used an updated version of the DIAMOND model (Rösevall et al., 2007) to treat the Odin observations. Two $\mathrm{O}_{3}$ fields are produced in the model, one is a passive $\mathrm{O}_{3}$ field that is only transported by advection and another one is an active $\mathrm{O}_{3}$ field that is modified by assimilation of the Odin/SMR data. The chemical $\mathrm{O}_{3}$ depletion can be derived by subtracting passive $\mathrm{O}_{3}$ from active $\mathrm{O}_{3}$.

\subsection{DIAMOND model}

The DIAMOND model is an off-line wind driven isentropic transport and assimilation model designed to simulate horizontal ozone transport in the lower stratosphere with low numerical diffusion (Rösevall et al., 2008). Horizontal off-line wind driven advection has been implemented using the Prather transport scheme (Prather, 1986) which is a mass conservative Eulerian scheme.

The idea of the Prather scheme is that by preserving the zero to second order moments of the sub-grid scale tracer distribution the quality of the transport is preserved. In this study, the wind fields obtained from the European Centre for Medium-Range 
Atmos. Chem. Phys. Discuss., doi:10.5194/acp-2016-352, 2016

Atmospheric

Chemistry

Manuscript under review for journal Atmos. Chem. Phys.

Published: 30 June 2016

(c) Author(s) 2016. CC-BY 3.0 License.

and Physics

Discussions

(c) (i)

Weather Forecasts (ECMWF) operational analyses have been used. Advection calculations are performed on separate layers with constant potential temperature (PT). Since PT in dry air is conservative under adiabatic conditions air parcels normally move on constant PT surfaces. However during polar night conditions considerable descent occurs within the polar vortex and because of the vertical gradients in ozone we must consider the effects of the vertical transport on the estimates of ozone loss.

5 A first-order upstream scheme was implemented in the current version of the model in order to take account of the vertical motion (Sagi et al., 2014). Since the general descent rate inside the vortex is approximately $1-2 \mathrm{~K}$ per day it is slow enough for the effects of numerical diffusion to be negligible. A vertical range of $425 \mathrm{~K}-950 \mathrm{~K}$ in PT, which corresponds to approximately $18-40 \mathrm{~km}$ altitude in the polar vortex, was selected for this study.

The tracer profiles from SMR are sequentially assimilated into the advection model. The assimilation scheme in DIAMOND can be described as a variant of the Kalman filter. Details of the assimilation scheme can be found in Rösevall et al. (2008).

\section{SMR ozone measurements}

The Odin satellite was launched into a sun-synchronous dawn-dusk polar orbit. SMR provides vertical profile measurements within the nominal latitude range $82.5^{\circ} \mathrm{S}$ and $82.5^{\circ} \mathrm{N}$ at 06:00/18:00 local time at the descending and ascending nodes respectively. In the stratospheric observation mode, two of the receivers, covering the bands centred at 501.8 and $544.6 \mathrm{GHz}$, are used for detecting the spectral emission lines of $\mathrm{O}_{3}, \mathrm{~N}_{2} \mathrm{O}, \mathrm{ClO}$ and $\mathrm{HNO}_{3}$. Stratospheric observation mode is operated every other day since April 2007 (every third day previous to this). The stratospheric ozone is retrieved from the two different emission lines centred at $501.8 \mathrm{GHz}$ and $544.6 \mathrm{GHz}$, using the Chalmers version 2.1 and 2.0 retrieval schemes, respectively. Figures 1 and 2 show typical ozone profiles, averaging kernels and errors estimated for the two frequencies for Arctic and Antarctic winters, respectively. The $501 \mathrm{GHz}$ ozone profiles cover the altitude range roughly $17-50 \mathrm{~km}$ with an altitude resolution of 2-3 km and an estimated single-profile precision of 1.5 parts per million volume (ppmv) (Urban et al., 2005). The filtering criterion used for this study is the measurement response, which is the sum of the rows of the averaging kernel and indicates how much information is derived from the true state in the atmosphere as opposed to coming from the a-priori information. In the analysis, ozone profiles with measurement of response of less than 0.8 have been excluded. It can be seen that $544 \mathrm{GHz}$ ozone measurements show greater sensitivity below $20 \mathrm{~km}$ than $501 \mathrm{GHz}$ ozone measurements . This difference can be clearly seen in the assimilated results as well. Validation of SMR v2.1 $501 \mathrm{GHz}$ ozone data has been performed against balloon sonde measurements as described by Jones et al. (2007). Since there is no validation paper available for SMR v2.0 544 GHz ozone, we show an internal comparison between two ozone data sets retrieved from the two frequencies used in this study. The internal comparison between the two ozone data sets is discussed in section 4.2 . 
Odin/SMR: 2010/03/15 8:42:11 (76.5N/117E) OC1BC0F7[11]

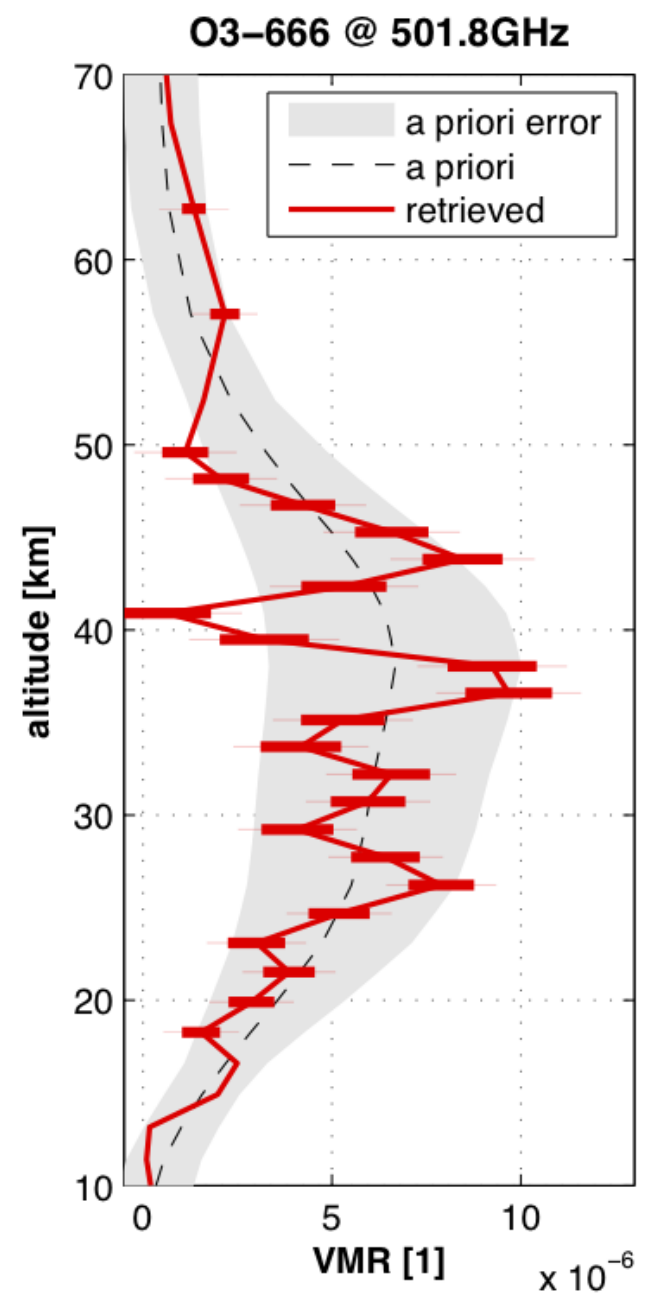

Averaging kernels

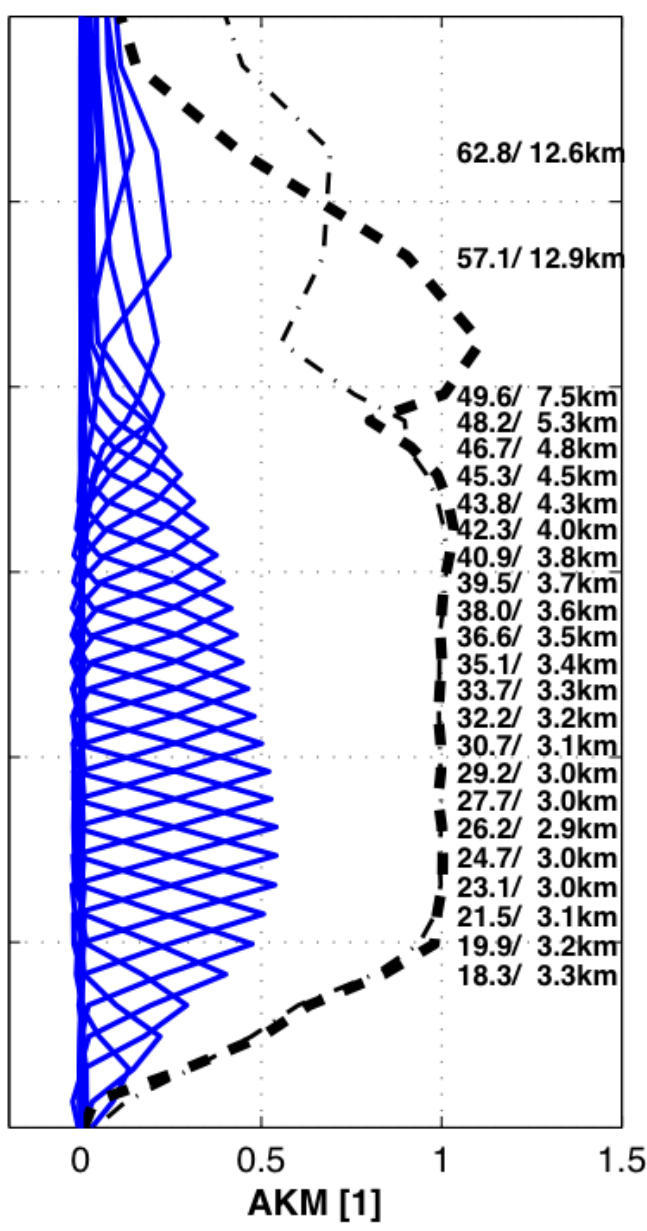

Absolute errors

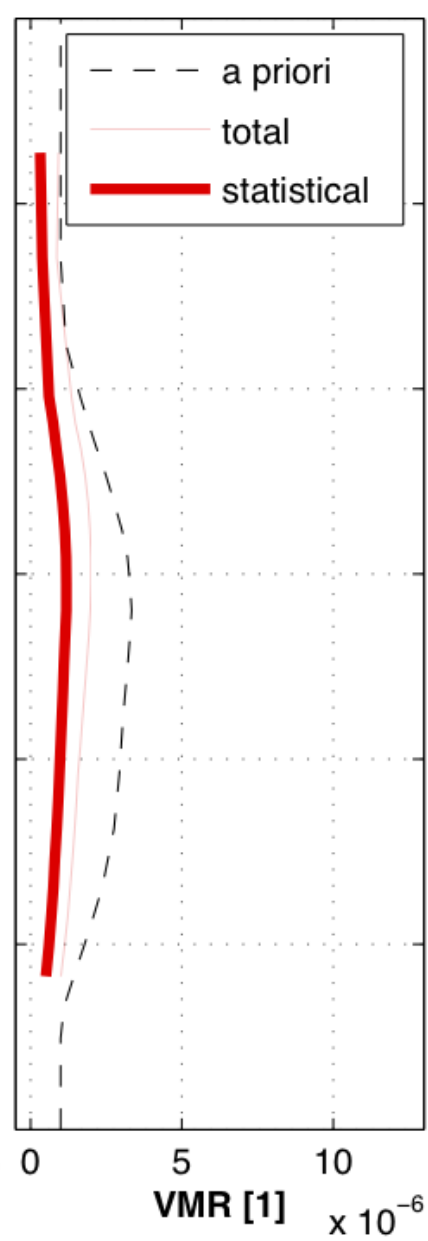

Figure 1. An example of the ozone retrieval using the emission centred at $501 \mathrm{GHz}$. The left, middle and right panels indicate the ozone profile, averaging kernels and error information, respectively. The retrieved data was taken at 2010/03/05 (YY/MM/DD) at 76.4N/117E degrees in latitude and longitude. In this study, we used ozone profiles within a vertical range of $425 \mathrm{~K}-950 \mathrm{~K}$ in PT, which corresponds to approximately $15-40 \mathrm{~km}$. 


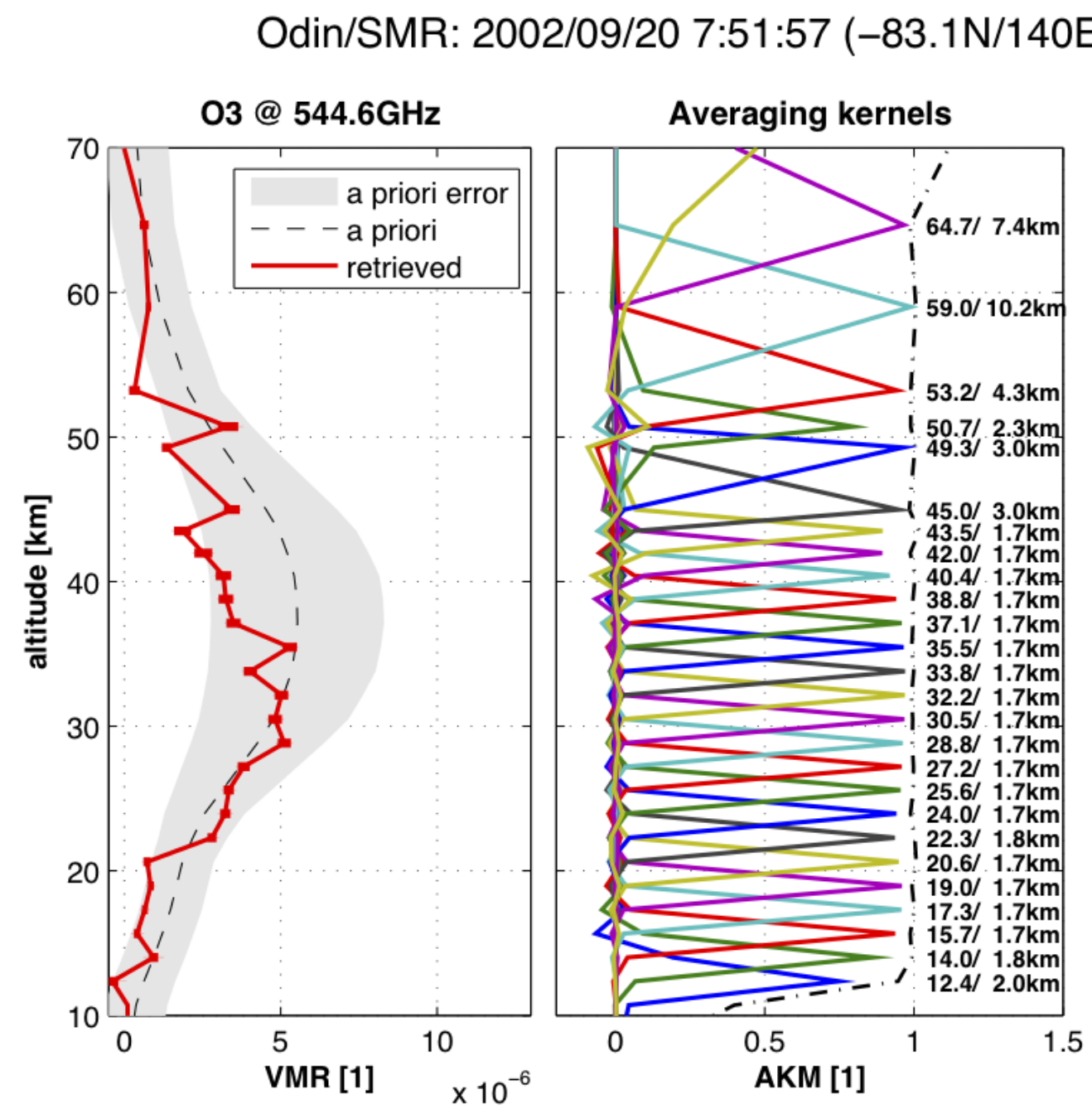

) OB1B217F[48]

Absolute errors

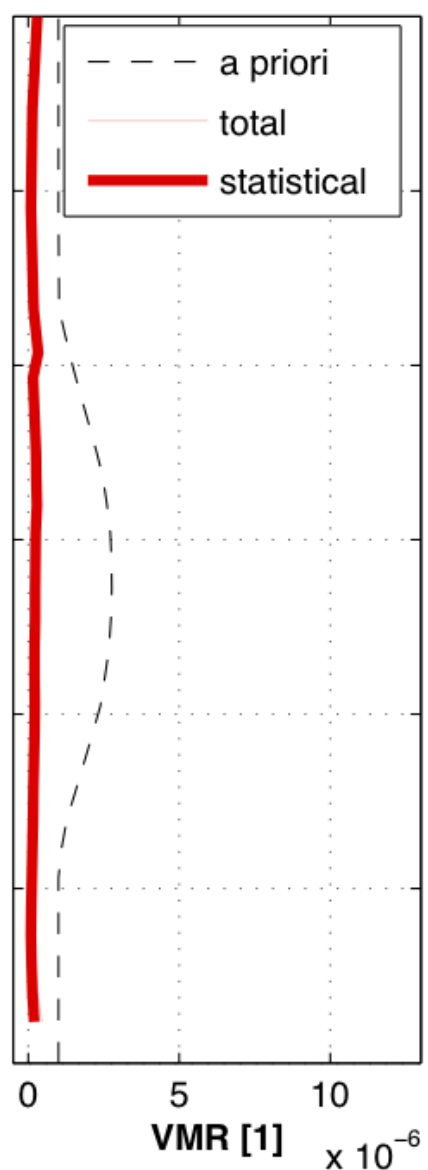

Figure 2. Same as figure 1 but for $544 \mathrm{GHz}$. The retrieved data were taken at 2002/09/20 (YY/MM/DD) at 83.1S/140E degrees in latitude and longitude.

\section{Results and Discussion}

\subsection{Defining the polar vortices}

The equivalent latitude (EQL) based on Lait's modified potential vorticity (PV) derived from the ECMWF operational data was used to determine the polar vortex edge (Lait, 1994). Nash et al. (1996) demonstrated that the maximum in the PV gradient is generally co-located with the maximum wind speed and thus can be used to define the polar vortex boundary. The maximum of the PV gradient typically occurs in the range of $60-70^{\circ}$ in EQL. The left panels in Fig. 3 and Fig. 4 show the daily mean EQLs 
Atmos. Chem. Phys. Discuss., doi:10.5194/acp-2016-352, 2016

Manuscript under review for journal Atmos. Chem. Phys.

Published: 30 June 2016

(c) Author(s) 2016. CC-BY 3.0 License.
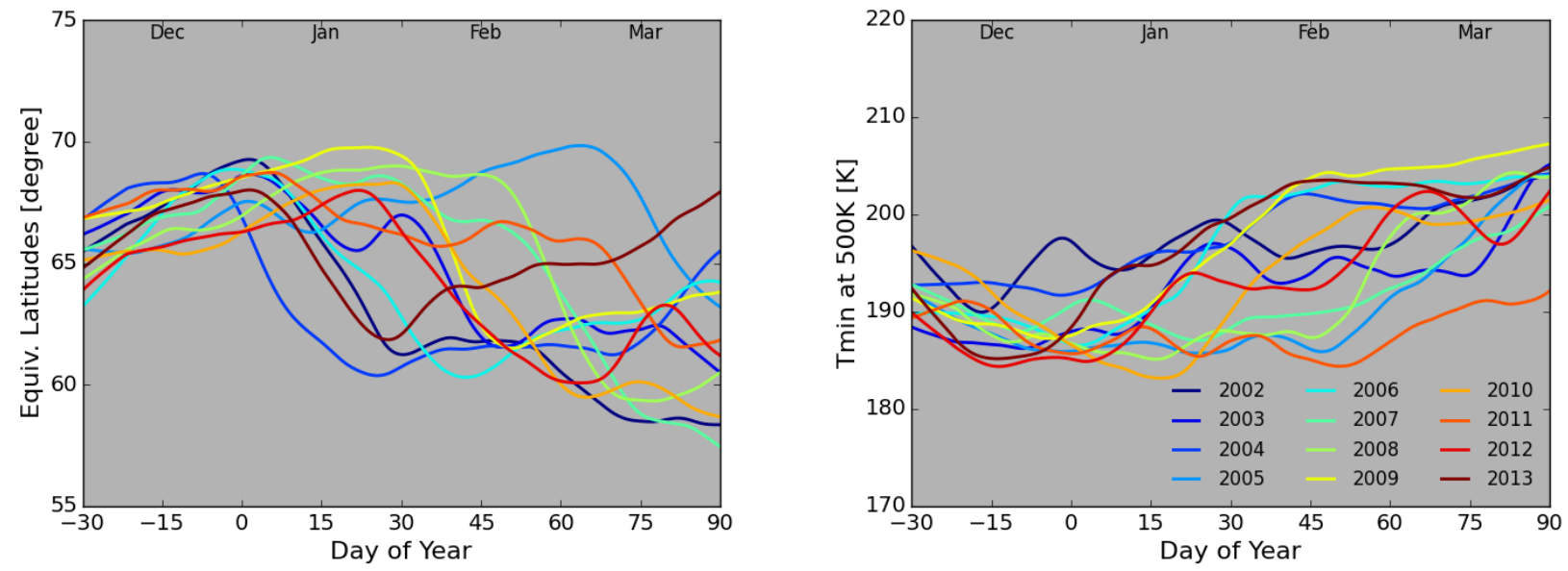

Figure 3. Left: Mean of equivalent latitudes in the Northern Hemisphere over the potential temperature surfaces between $425 \mathrm{~K}$ and $950 \mathrm{~K}$ $(90-7 \mathrm{hPa}$ in pressure and $15-40 \mathrm{~km}$ in altitudes) where the gradient of potential vorticity has maximum value as a function of day of year. Right: Minimum temperature inside the vortex at $500 \mathrm{~K}$ in the Northern Hemisphere as a function of day of year. PV and temperature data were taken from ECMWF operational data provided at 6 hourly temporal resolution. Each colour indicates the year referred in the legend.
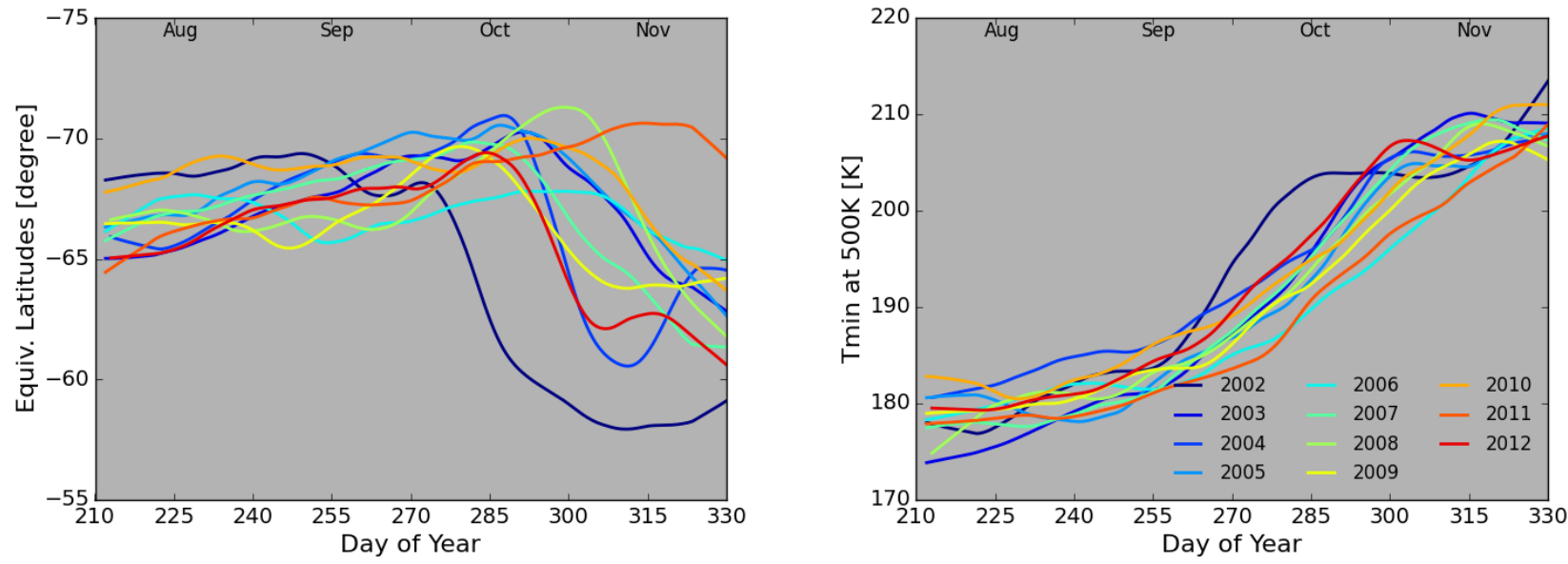

Figure 4. Same as figure 3 but for the Southern Hemisphere.

corresponding to the maximum gradient in PV for the Northern and Southern Hemispheres, respectively for the PT range of

$5425-950 \mathrm{~K}$ ( $90-7 \mathrm{hPa}$ in pressure and $15-40 \mathrm{~km}$ in altitude). As we noted, the position of the maximum gradient of PV varies within the range of $60-70^{\circ} \mathrm{EQL}$ in both hemispheres until the break up of the vortex in spring. The Northern Hemisphere 
Atmos. Chem. Phys. Discuss., doi:10.5194/acp-2016-352, 2016

Atmospheric

Chemistry

Manuscript under review for journal Atmos. Chem. Phys.

Published: 30 June 2016

(c) Author(s) 2016. CC-BY 3.0 License.

and Physics

Discussions

(c) (i)

shows greater variation in the position of the vortex edge while the values for different years follow each other closely until the end of September in the Southern Hemisphere. The variability is closely related to the stability of the polar vortex in the respective hemispheres. The right panels in Fig. 3 and Fig.4 show the minimum temperature for EQL greater than $70^{\circ}$ at

$5500 \mathrm{~K}(\sim 20 \mathrm{~km})$ for both hemispheres. In the warmer winters affected by a SSW event, for instance 2003/2004, 2005/2006, 2008/2009, 2012/2013 in the Arctic, and 2002 in the Antarctic, the position of the maximum gradient moves toward lower latitudes just after the increase in temperature. During such periods, the vortex is very weak and intra- and extra-vortex air is mixed near the vortex edge. In some winters (e.g., Arctic winter 2012/2013) the vortex subsequently recovers and remains until spring. In order to be sure to sample air that is inside the vortex, we have used EQL of $70^{\circ}$ as the vortex boundary in the following sections.

\subsection{Comparison between $501 \mathrm{GHz}$ and $544 \mathrm{GHz}$ ozone}

To ensure the validity of our conclusions we need to place the current data in context. In this section we perform an internal comparison of the two sets of SMR ozone measurements and in the following section, a comparison with other studies using different techniques and instruments.

5 The left panel in Fig. 5 indicates the vortex mean ozone profile in March over the selected years between 2002 and 2013 in the Northern Hemisphere. In order to calculate the vortex average, we have used the two ozone fields where the SMR $501 \mathrm{GHz}$ and $544 \mathrm{GHz}$ ozone measurements have been assimilated independently. The red and blue lines show the results of assimilation using SMR ozone measurements retrieved from emission lines at $501 \mathrm{GHz}$ and $544 \mathrm{GHz}$, respectively. The ozone average in the Antarctic vortex in October over the years between 2003 and 2012 is also presented in Fig. 6. The grid points considered as being inside the vortex using the edge criterion $\left( \pm 70^{\circ}\right)$ for the months of March/October in the Northern/Southern Hemisphere respectively were used to calculate the average as a function of PT. The middle and right panels in Fig. 5 and Fig. 6 present absolute and relative differences between $501 \mathrm{GHz}$ ozone and $544 \mathrm{GHz}$ ozone inside the

5 Arctic and Antarctic vortex for the selected periods, respectively. Each box contains 50\% of differences, while horizontal bars (whiskers) indicate the range between the minimum and the maximum differences. The median of differences can be seen as the red line in the boxes. Above a PT of $550 \mathrm{~K}$, the two ozone sets match each other in the range of volume mixing ratio (VMR) between 0.1 and 0.3 ppmv (less than $10 \%$ deviation). The deviation varies between 0.1 and 0.3 ppmv in all altitudes in both hemispheres, except in the Southern Hemisphere below $550 \mathrm{~K}$ with approximately 0.5 ppmv differences. In both hemispheres $501 \mathrm{GHz}$ ozone is $0.2 \mathrm{ppmv}$ higher than $544 \mathrm{GHz}$ ozone above $700 \mathrm{~K}$, while $501 \mathrm{GHz}$ ozone is 0.1 ppmv lower than $544 \mathrm{GHz}$ ozone in the range between $700 \mathrm{~K}$ and $550 \mathrm{~K}$. According to the averaging kernels from Fig. 1 and Fig. 2, the vertical resolution of $501 \mathrm{GHz}$ ozone is larger than $544 \mathrm{GHz}$ ozone, thus the $501 \mathrm{GHz}$ ozone value contains more information from higher levels. In addition, the assimilated $501 \mathrm{GHz}$ ozone reflects more model information than observation information due to smaller precision at this height. However this positive bias is relatively small (5\%) for both hemispheres. Large differences occur in height regions where ozone depletion occurs. This can be also explained by the lower precision and the sparsity of the $501 \mathrm{GHz}$ ozone measurements. Especially in the Southern Hemisphere there are significantly larger differences below $500 \mathrm{~K}$ because of the precision and the vertical resolution of measurements. The same comparisons have been performed with raw SMR level 2 
Atmos. Chem. Phys. Discuss., doi:10.5194/acp-2016-352, 2016

Manuscript under review for journal Atmos. Chem. Phys.

Published: 30 June 2016

(C) Author(s) 2016. CC-BY 3.0 License.
Atmospheric

Chemistry

and Physics

Discussions

(c) (i)

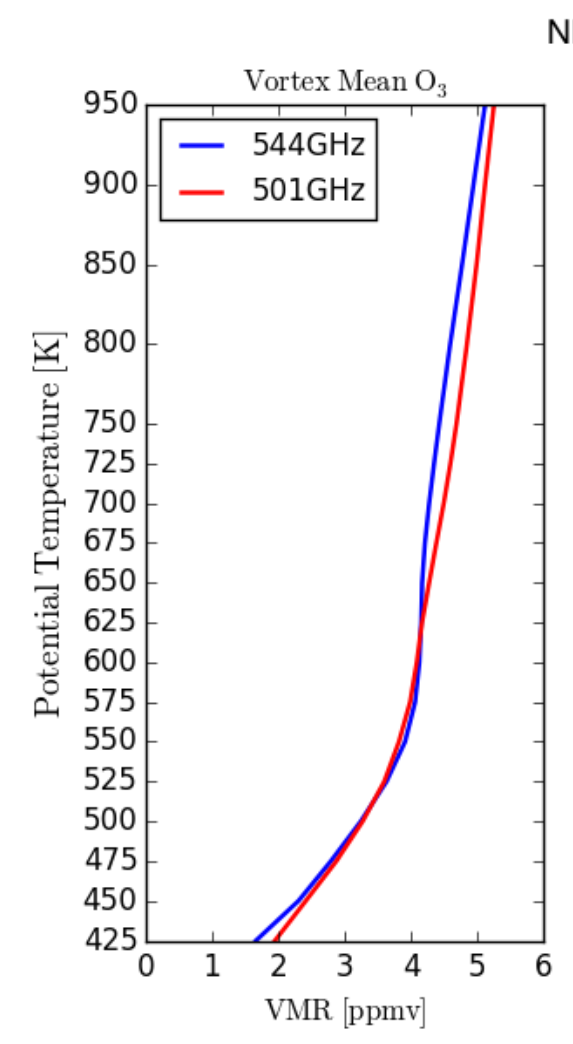

NH 2002-2013 March EQL [70N-90N]
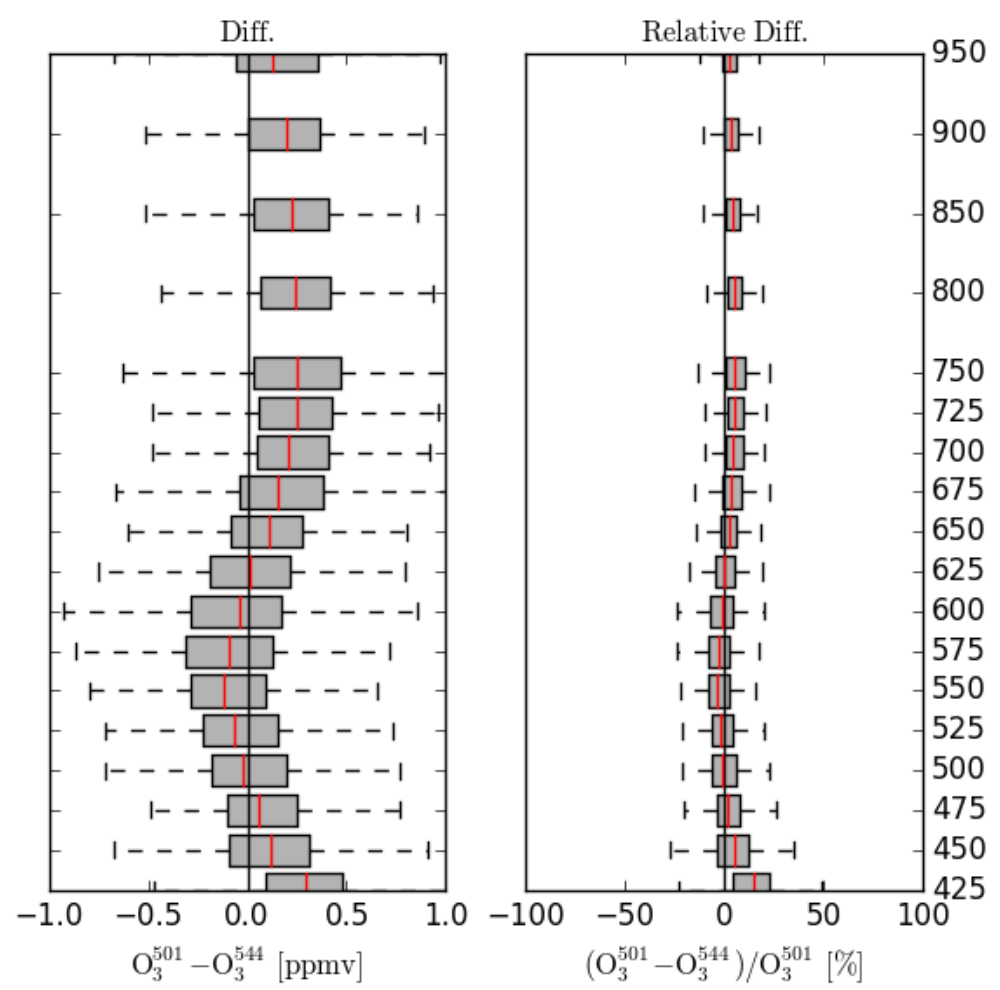

Figure 5. Left panel: The vortex mean ozone in March over the selected Arctic winters between 2002 and 2013. The red and blue lines show the results of assimilation using SMR ozone measurements retrieved from emission lines at $501 \mathrm{GHz}$ and $544 \mathrm{GHz}$, respectively. For the vortex average, the EQL of $70^{\circ} \mathrm{N}$ is used as the vortex edge. Middle and left panels: Absolute and relative differences between vortex mean ozone using $501 \mathrm{GHz}$ ozone and $544 \mathrm{GHz}$ ozone, respectively. The left and right sides of each box show the second (25\%) and the third quartiles (75\%), while whiskers indicate a range between the minimum and the maximum differences. Red lines inside each of the boxes represent the median. The positive difference shows where $501 \mathrm{GHz}$ ozone has a larger value than $544 \mathrm{GHz}$, while the negative difference shows where $544 \mathrm{GHz}$ ozone has a larger value than $501 \mathrm{GHz}$.

ozone measurements as well as active ozone. The results (not shown here) have similar biases to the active ozone comparisons, while they have larger spread around the medians due to lack of constraint by the numerical transport model. Thus, from section 4.4, we only show the results using $544 \mathrm{GHz}$ ozone.

\subsection{Comparison with other studies}

A detailed comparison of the ozone loss derived from $501 \mathrm{GHz}$ ozone with SMILES in a specific Arctic winter i.e. 2009/2010 has been presented by Sagi et al. (2014). The comparison concluded that our estimation of the ozone loss is approximately 0.3 ppmv lower than other studies (Kuttippurath et al., 2010; Hommel et al., 2014; Wohltmann et al., 2013) . In Sagi et al. (2014) 
Atmos. Chem. Phys. Discuss., doi:10.5194/acp-2016-352, 2016

Manuscript under review for journal Atmos. Chem. Phys.

Published: 30 June 2016

(C) Author(s) 2016. CC-BY 3.0 License.
Atmospheric

Chemistry

and Physics

Discussions

(c) (1)

SH 2003-2012 October EQL [70S-90S]
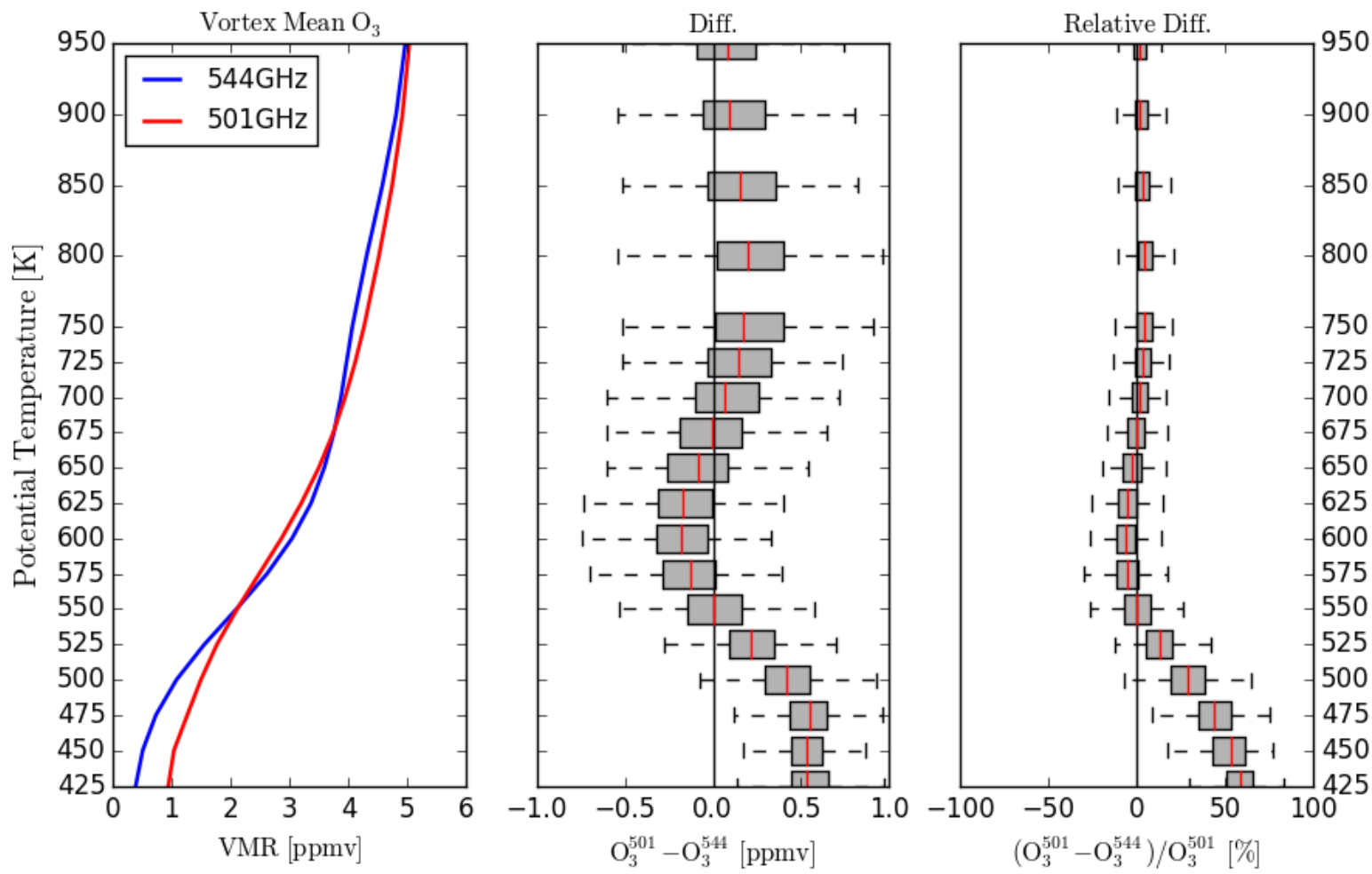

Figure 6. Same as figure 5 but for October in the Southern Hemisphere. We excluded the results in the 2002 Antarctic winter, since the SSW event occurred in this winter. For the vortex average, the EQL of $70^{\circ} \mathrm{S}$ is used as a vortex edge.

plausible explanations for the differences are discussed as results of sampling effect including the vertical resolutions of the ozone profiles and different criteria for defining the vortex edge.

Sonkaew et al. (2013) derived ozone loss from SCIAMACHY ozone profiles using the vortex average method for the Arctic winters 2002/2003-2008/2009 and the Antarctic winters 2003/2004--2007/2008. Sonkaew et al. (2013) have compared their estimation of ozone loss in the 2004/2005 Arctic vortex with other previous studies (e.g., Jin et al., 2006; El Amraoui et al., 2008; Manney et al., 2006; Rösevall et al., 2008; Singleton et al., 2007) .

In this section we have selected Sonkaew et al. (2013) as a reference in order to compare with our estimation of ozone loss derived from both $501 \mathrm{GHz}$ and $544 \mathrm{GHz}$ measurements. In addition we also used the loss investigated by Rösevall et al. (2008) for the comparison with the previous version of the DIAMOND model. Figure 7 shows the vertical profiles of the chemical ozone change during the 2004/2005 winter calculated by Sonkaew et al. (2013) and Rösevall et al. (2008) with our results from two ozone data sets. Note that the study periods are different. The time period of our estimation was chosen to be 1 December 2004 to 14 March 2005, to allow the best comparison with the studied period of 1 January to 14 March by Rösevall et al. (2008) and the best compromise with the period of 1 January to 10 March by Sonkaew et al. (2013) . In Fig. 
Atmos. Chem. Phys. Discuss., doi:10.5194/acp-2016-352, 2016

Manuscript under review for journal Atmos. Chem. Phys.

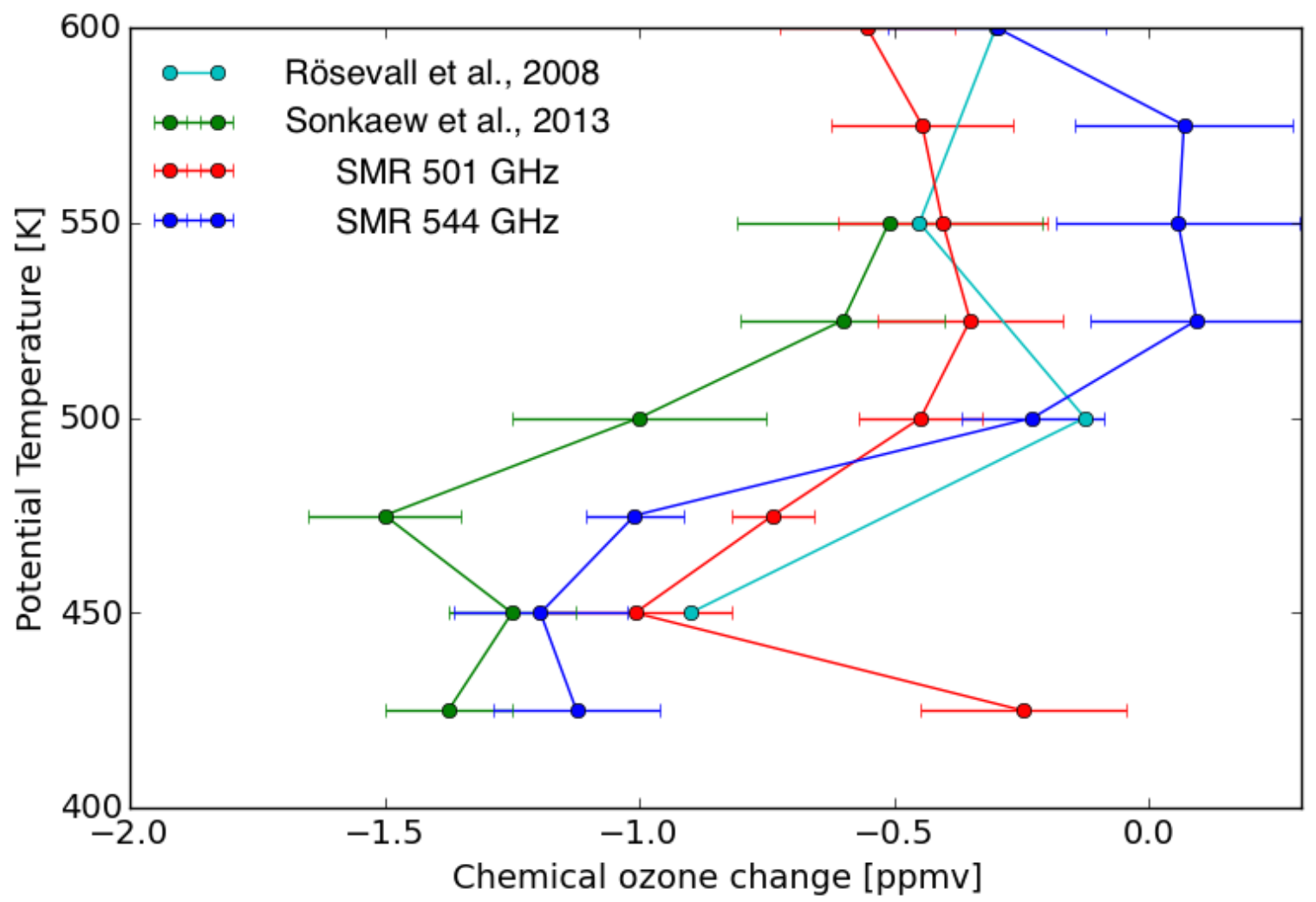

Figure 7. Comparison of the vertical profiles of the chemical ozone change during the 2004/2005 Arctic winter derived from Sonkaew et al. (2013) (indicated as a green line) and Rösevall et al. (2008) (indicated as a light blue line) based on different time periods and different instruments. The red and blue lines present vertical profiles of chemical ozone change derived from this study using SMR $501 \mathrm{GHz}$ ozone measurements and SMR $544 \mathrm{GHz}$ ozone measurements, respectively. Analysis periods are 1 January to 10 March for Sonkaew et al. (2013); 1 January to 14 March for Rösevall et al. (2008); 1 December 2004 to 14 March for this study.

7 the chemical ozone loss found by Rösevall et al. (2008) is the smallest below $500 \mathrm{~K}$. Rösevall et al. (2008) also assimilated SMR $501 \mathrm{GHz}$ ozone into the previous version of the DIAMOND. Thus the difference between Rösevall et al. (2008) and our $501 \mathrm{GHz}$ result indicates the improvement introduced by the better attention paid to the vertical transport scheme in the new version of the DIAMOND. Below $450 \mathrm{~K}$ our $544 \mathrm{GHz}$ loss is in good agreement with Sonkaew et al. (2013). However we still have about 0.2 ppmv less loss than Sonkaew et al. (2013). This discrepancy in ozone depletion is not only for 2004/2005 winter but also the other Arctic winters. In general we have $0.1 \sim 0.2$ ppmv lower ozone loss than SCIAMACHY. This can be explained by the definition of the polar vortex. Since the maximum gradient of PV is not constant in time, we adopted EQL of $70^{\circ}$ as the vortex edge to ensure uniformity of each vortex mean in this study, while Sonkaew et al. (2013) used modified $\mathrm{PV}$ of $38 \times 10^{-6} \mathrm{~m}^{2} \mathrm{~s}^{-1} \mathrm{Kg}^{-1}$ as the threshold of the vortex boundary. This PV criterion gives slightly larger area than the EQL 
Atmos. Chem. Phys. Discuss., doi:10.5194/acp-2016-352, 2016

Atmospheric

Chemistry

Published: 30 June 2016

(c) Author(s) 2016. CC-BY 3.0 License.

and Physics

Discussions

(c) $\underset{\mathrm{By}}{\mathrm{i}}$

criterion in March 2005 (see Fig. 3). Using the PV vortex criterion rather than the EQL vortex criterion for the 2004/2005 winter resulted in $\sim 0.1$ ppmv higher loss. Another candidate to explain the lower loss estimation is a particular assimilation issue. An advantage of data assimilation is that we can get reasonable interpolation of ozone fields in time and space. However we note that the average over the vortex is potentially contaminated by information coming from outside the vortex since active ozone fields are modified by measurements both inside and outside vortex due to the way the increments are spatially spread. Jackson and Orsolini (2008) quantified ozone loss in 2004/2005 using data assimilation of Earth Observing System Microwave Limb Sounder (EOS MLS) and Solar Backscatter Ultraviolet radiometer (SBUV/2) ozone observations, which is a similar ozone loss estimation technique to our own method. Jackson and Orsolini (2008) estimated the ozone loss between February 1 and March 10 to be $0.6 \mathrm{ppmv}$ and $0.4 \mathrm{ppmv}$ at $450 \mathrm{~K}$ and $650 \mathrm{~K}$, respectively. This is lower than other studies not using the assimilation technique (e.g. Grooß and Müller, 2007; Singleton et al., 2007). However their estimation did not take into account the loss during January 2005. Thus Jackson and Orsolini (2008) concluded that the loss in 2004/2005 would reach 0.8 - 1.2 ppmv, if the loss in January was included. Another study of ozone loss in 2004/05 based on data assimilation was made using Aura/MLS measurements (El Amraoui et al., 2008). Our estimation of assimilated $544 \mathrm{GHz}$ ozone is in better agreement with El Amraoui et al. (2008) except that the maximum loss peaks at $425 \mathrm{~K}$ and $450 \mathrm{~K}$ from $544 \mathrm{GHz}$ and Aura/MLS, with values of $1.2 \mathrm{ppmv}$ and $1.5 \mathrm{ppmv}$ respectively. Thus we do not find any clear problem due to the data assimilation technique. A significant difference can be seen around PT of $550 \mathrm{~K}$. At this height $544 \mathrm{GHz}$ does not have any loss even if other three data sets show approximately 0.5 ppmv loss. We conjectured that SCIAMACHY and SMR $501 \mathrm{GHz}$ ozone measurements have lower vertical resolutions (more than $3 \mathrm{~km}$ below $20 \mathrm{~km}$ ) than $544 \mathrm{GHz}$ ozone $(1.7 \mathrm{~km}$ below $20 \mathrm{~km}$ ), and thus the loss at $550 \mathrm{~K}$ derived from SCIAMACHY and SMR $501 \mathrm{GHz}$ ozone includes losses below $500 \mathrm{~K}$ and above $600 \mathrm{~K}$. However, we have good agreement with Sonkaew et al. (2013) on the temporal characteristics and the altitude of peak ozone loss below $600 \mathrm{~K}$ in the Northern and Southern Hemisphere in the other years.

We have also compared ozone losses in the Southern Hemisphere with Kuttippurath et al. (2015). They have applied the passive tracer method to quantify Antarctic ozone holes between 2004 and 2013 using the Mimosa-Chim chemical transport model and the Aura MLS ozone measurements (Froidevaux et al., 2008). We have good agreement with MLS ozone loss within 0.1 ppmv, while consistently 0.3 ppmv lower in our estimation compared to the Mimosa-Chim loss. Kuttippurath et al. (2015) discussed that they have 0.2-0.5 ppmv difference between the Mimosa-Chim and MLS loss, which is primarily due to the slower descent in the model. In addition, they used a larger vortex area (EQL of $\left.<65^{\circ} \mathrm{S}\right)$ for their calculation, where air much closer to the vortex edge is also included. This air is subject to additional chemical loss in the lower stratosphere. The above comparisons leads to the conclusion that our quantification of the ozone loss is consistent with other instruments and techniques. 
Atmos. Chem. Phys. Discuss., doi:10.5194/acp-2016-352, 2016

Manuscript under review for journal Atmos. Chem. Phys.

Published: 30 June 2016

(C) Author(s) 2016. CC-BY 3.0 License.
Atmospheric

Chemistry

and Physics

Discussions

(c) (i)
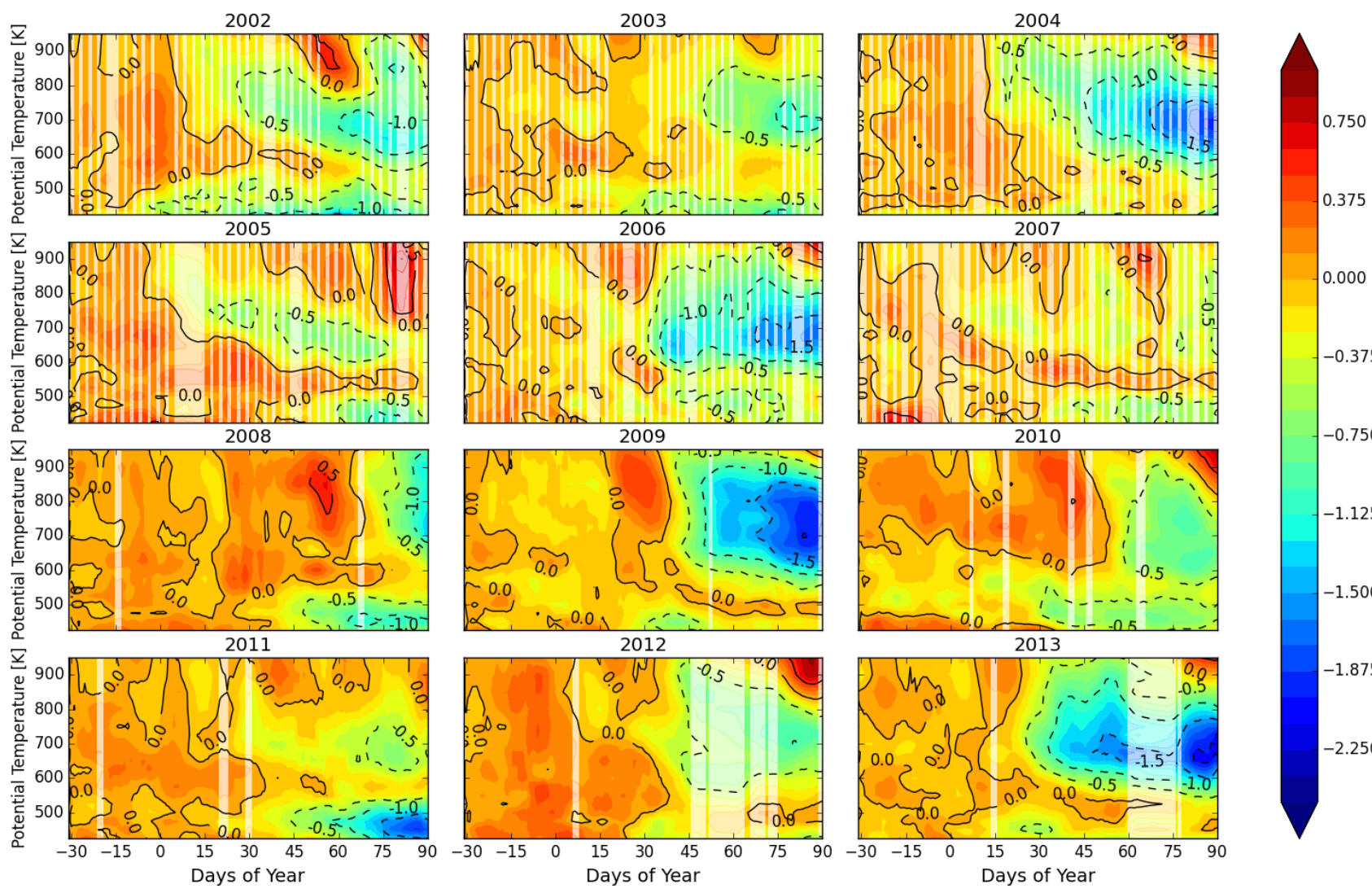

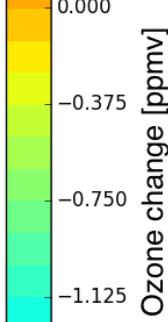
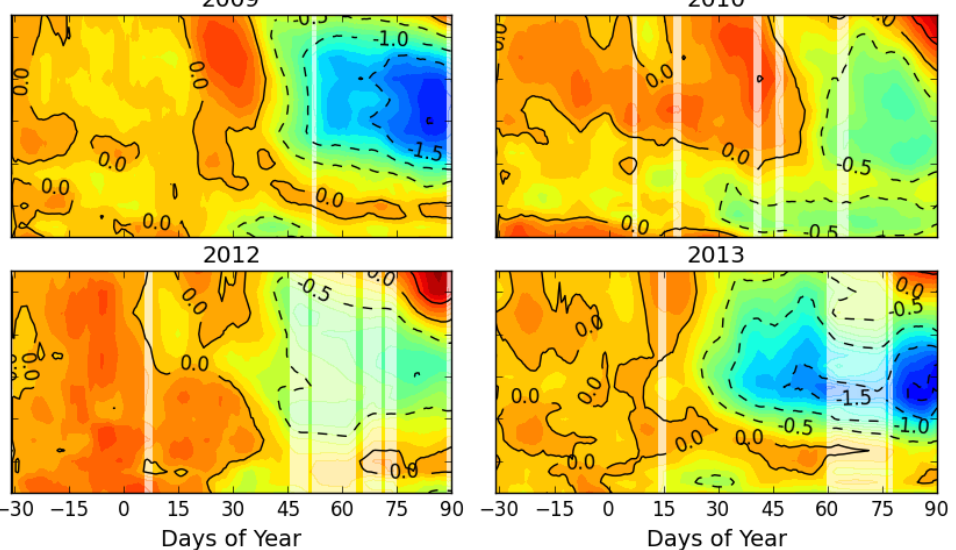

Figure 8. Vortex mean ozone change for selected Northern winters, calculated using active ozone from 544 GHz measurements. The shaded areas indicate periods when no measurements are available and thus the estimated ozone loss abundance is only affected by the transport during these periods. The red/blue colours show positive/negative ozone changes, respectively.

\subsection{Inter-annual variability in chemical ozone loss}

\subsubsection{Arctic ozone loss}

We have estimated ozone losses in the Northern Hemisphere between 2001/2002 and 2012/2013. The analysis period for each year is during day of year (DOY) of -31 to 90, corresponding to 1 December and 30-31 March respectively. Figure 8 shows the time evolution of the Arctic ozone depletion inside the vortex (EQL $\geq 70^{\circ}$ ) for the selected years (2001/2002-2012/2013). In each panel the vortex mean of ozone loss for selected Northern winters is calculated using assimilation of $544 \mathrm{GHz}$ ozone measurements. The shaded areas indicate the periods when no measurements are available in the assimilation process and thus the estimated ozone loss abundance is only affected by the transport during these periods. 
Atmos. Chem. Phys. Discuss., doi:10.5194/acp-2016-352, 2016

Manuscript under review for journal Atmos. Chem. Phys.

Published: 30 June 2016

(c) Author(s) 2016. CC-BY 3.0 License.
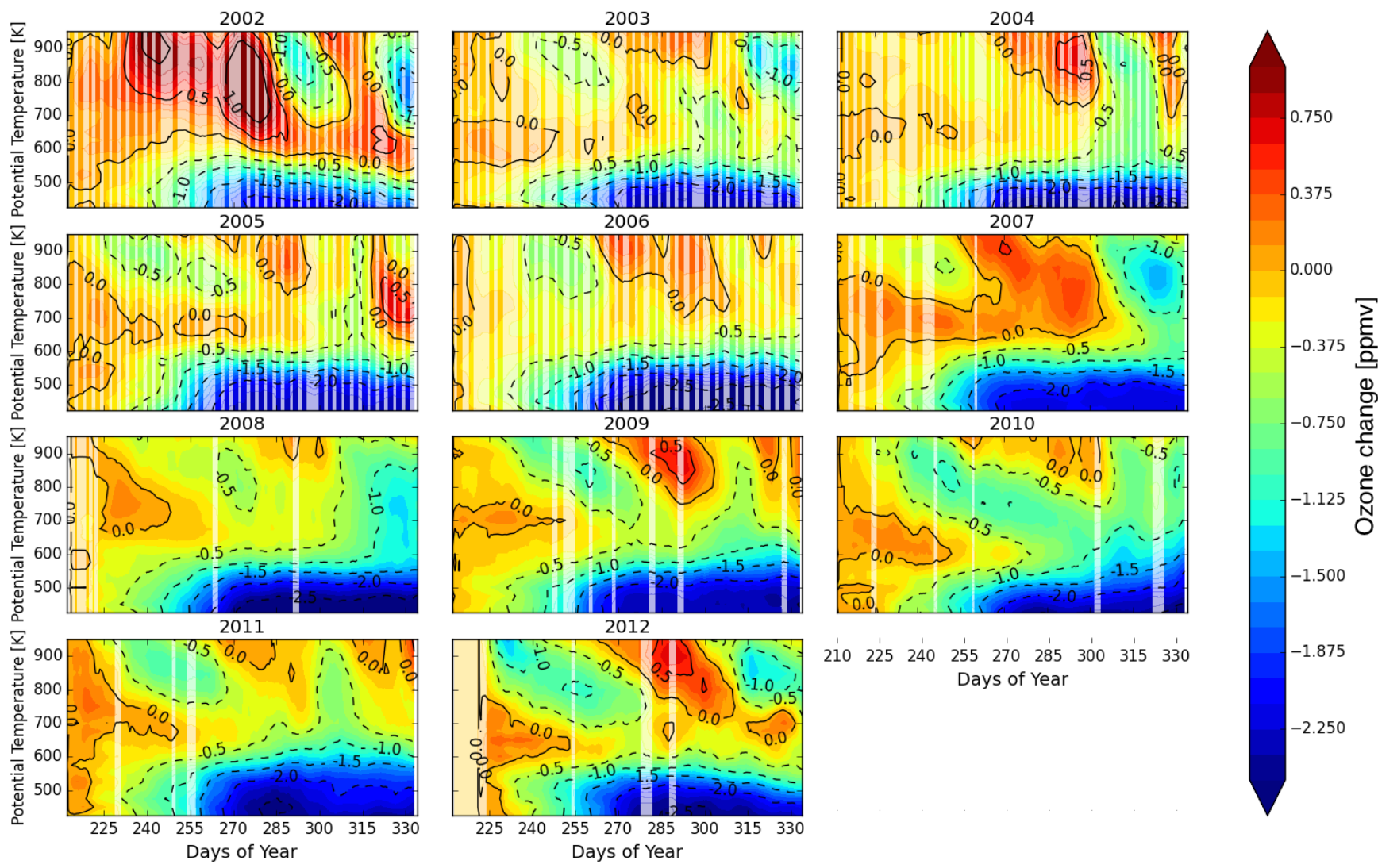

Figure 9. Same as Fig. 8 but for vortex mean ozone change for selected Southern winters, calculated using active ozone of $544 \mathrm{GHz}$ measurements.

The effects of the inter-annual variability are seen in the figure. The winters of 2004/2005, 2007/2008 and 2010/2011 are the three coldest winters in February (see Fig. 3). In such conditions in the Northern Hemisphere, a relatively strong polar vortex sustains its isolation. Major ozone depletion began in mid-February below $500 \mathrm{~K}$ and continued until the break up of the vortex. The largest ozone loss below $500 \mathrm{~K}$ occurred in 2010/2011, and reached 2.1 ppmv in volume mixing ratio at the end of March at $450 \mathrm{~K}$. This is in line with current understanding of the chemical loss mechanism where the main factor is chlorine activation by heterogeneous reactions on PSC (e.g. Jin et al., 2006; Kuttippurath et al., 2009; Sonkaew et al., 2013).

In contrast to the Antarctic winters (see below) a significant difference for the Arctic is the loss of more than 2 ppmv between $600-800 \mathrm{~K}$ for the winters of 2003/2004, 2005/2006, 2008/2009 and 2012/2013. The occurrence of major mid-winter SSW and the attending warmer temperature in the lower stratosphere are common to those winters. Similar ozone decreases are seen in previous studies, e.g., Sonkaew et al. (2013), Kuttippurath et al. (2010) and Konopka et al. (2007). $\mathrm{NO}_{x}$ photochemistry has been suggested to be important for ozone loss in this altitude range (Osterman et al., 1997) . $\mathrm{NO}_{x}$-driven ozone loss is stronger 
Atmos. Chem. Phys. Discuss., doi:10.5194/acp-2016-352, 2016

Manuscript under review for journal Atmos. Chem. Phys.

Published: 30 June 2016

(c) Author(s) 2016. CC-BY 3.0 License.

during warm winters, since the polar vortex is weaker and less denitrification is generated due to subsidence of PSC. There are two possible reasons for the $\mathrm{NO}_{x}$ increase inducing loss in early spring above $600 \mathrm{~K}$. One is a downward transport from the upper stratosphere and the mesosphere inside the vortex, and another is the horizontal transport of $\mathrm{NO}_{x}$-rich air from mid-latitudes (Rosenfield et al., 1994; Konopka et al., 2007). Konopka et al. (2007) investigated the Arctic loss using POAM (Polar Ozone and Aerosol Measurement III) and MIPAS (Michelson Interferometer for Passive Atmospheric Sounding) ozone measurements in 2002/2003 when a combination of Halogen-induced loss and $\mathrm{NO}_{x}$-driven loss took place. In that study Konopka et al. (2007) found the occurrence of more than 2 ppmv ozone loss around $700 \mathrm{~K}$ in April. Compared to the Konopka

5 et al. (2007) estimate of ozone loss at the end of March 2003 (DOY of $~ 90$ ), our estimate is approximately 0.5 ppmv lower. One possible reason is that they used a larger vortex area to average the loss (EQL of 65 degrees). However we find high similarity in the shapes of ozone loss vertical profiles between ours and those from Konopka et al. (2007). Konopka et al. (2007) concluded that horizontal transport dominantly generated ozone destruction above $600 \mathrm{~K}$ in this year. Figure 8 shows that the horizontal transport of $\mathrm{NO}_{x}$ is rather efficient in warmer winters. An additional study is in progress to generalise the characteristics of the two mechanisms behind Arctic ozone loss, i.e. classical Halogen-induced loss and $\mathrm{NO}_{x}$-driven loss and will be published separately.

\subsubsection{Antarctic ozone hole}

The more stable conditions for the vortex over Antarctica produces larger scale ozone loss compared to the Arctic. Therefore chemical ozone loss during Antarctic winters does not have as large inter-annual variability as in the Northern Hemisphere. However, although similar, the inter-annual variability of Antarctic springtime total ozone has been observed to be larger over the last decade compared to the 1990s (WMO, 2014). The chemical losses over the Antarctica derived in this study as seen in Fig. 9 are very similar with typical loss beginning in mid-August and continuing until the end of September, corresponding to DOY of $\sim 230-270$. The typical estimated losses in Southern winters exceed 2.5 ppmv below $450 \mathrm{~K}$. This corresponds to approximately $70 \%$ of the stratospheric partial column. Several previous studies(WMO, 2014; Kuttippurath et al., 2015; Tilmes et al., 2006; Sonkaew et al., 2013) have suggested that the loss rate has been decreasing. A reason for this deceleration of loss is that most of the ozone has been destroyed in an isentropic range between $550 \mathrm{~K}$ and $425 \mathrm{~K}$ leading to a tail off in loss below $450 \mathrm{~K}$ in October (DOY of 270-300) in Fig. 9. As discussed in the previous section, horizontal transport of $\mathrm{NO}_{x}$-rich air from sub-tropical regions induces ozone depletion in the middle stratosphere in the Northern Hemisphere. In the Southern Hemisphere loss above $700 \mathrm{~K}$ also appears in November (after 310 DOY), however the magnitude is relatively small (generally less than 1 ppmv). This can be caused by the horizontal mixing as a result of vortex breakup associated with the final warming.

Another feature in the Stratospheric ozone in the Southern Hemisphere was reported by Fytterer et al. (2015). The descent of $\mathrm{NO}_{x}$ created by auroral processes and solar proton events (SPEs) in the mesosphere / lower thermosphere is transported down to the stratosphere during polar winter, where it can affect the ozone concentration. In order to reveal the contribution of energetic

5 particle precipitation (EPP) to stratospheric ozone, Fytterer et al. (2015) investigated ozone behaviour inside the Antarctic polar vortex using composite ozone observed by three satellite instruments Environmental Satellite (ENVISAT) / Michelson Interferometer for Passive Atmospheric Sounding (MIPAS), Odin/SMR, and Thermosphere Ionosphere Mesosphere Energetics 


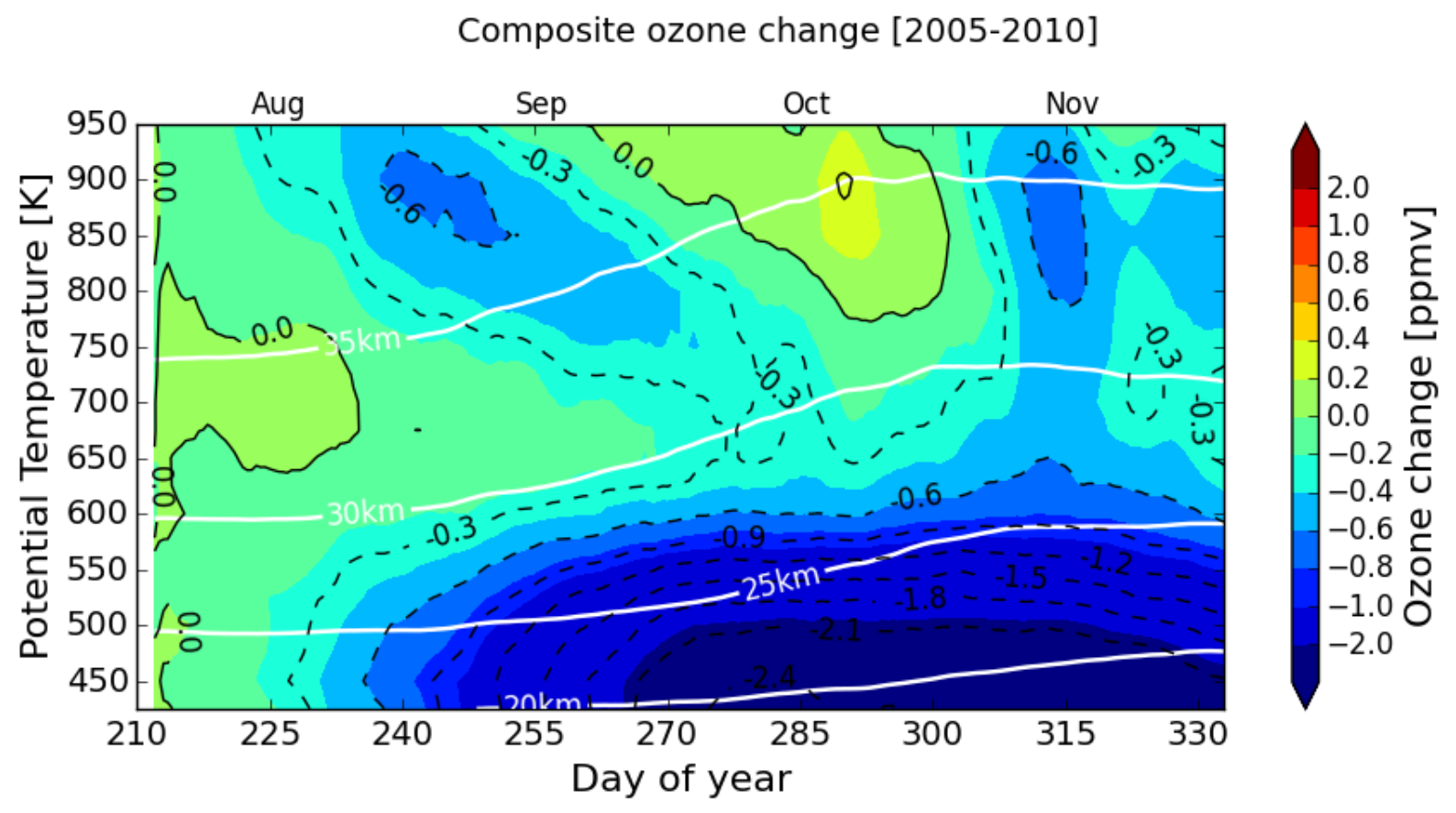

Figure 10. Composite of vortex mean ozone change in the Southern Hemisphere over years between 2005 and 2010 for comparison with figure 5 in Fytterer et al. (2015). We selected 1 September in each year as a reference date for the composite. White contour lines indicate approximate altitudes with a resolution of $5 \mathrm{~km}$.

and Dynamics (TIMED) / The Sounding of the Atmosphere using Broadband Emission Radiometry (SABER). They neglected the direct effect of the solar radiation by only considering years between 2005 and 2010 when solar minimum activity occurred. They found an anti-correlation between geomagnetic activity and stratospheric ozone. Figure 9 shows downward propagation of ozone changes between $600 \mathrm{~K}$ and $950 \mathrm{~K}$ from the beginning of August until mid-November in all years except for 2002 which is characterised by the unusual for the Antarctic occurrence of a SSW event. This propagating ozone loss structure is coincident with the downward propagation of negative response in composite ozone to the 1 April Ap index, which is commonly used as a proxy for geomagnetic activity, presented in Fig. 5 of Fytterer et al. (2015). Fytterer et al. (2015) also found that their negative response in ozone was consistent with positive $\mathrm{NO}_{2}$ response to the 1 April Ap index. Hence Fytterer et al. (2015) made mention of geomagnetic activity and $\mathrm{NO}_{x}$ contributions to ozone depletion, however they could not draw any strong conclusions given the relatively short time series of 6 years.

Figure 10 presents a composite of vortex mean ozone change over years selected in Fytterer et al. (2015) derived from our results. The downward propagation of loss from the upper stratosphere and the $\mathrm{NO}_{x}$-driven loss above $700 \mathrm{~K}$ due to the final warming are more clearly seen in the figure. Our chemical ozone change is not exactly the same as the ozone response to Ap index presented by Fytterer et al. (2015) but lends support to their hypothesis. 
Atmos. Chem. Phys. Discuss., doi:10.5194/acp-2016-352, 2016

Manuscript under review for journal Atmos. Chem. Phys.

Published: 30 June 2016

(C) Author(s) 2016. CC-BY 3.0 License.

\section{(c) (i)}

Atmospheric

Chemistry

and Physics

Discussions

\subsubsection{Partial column losses}

In this section we discuss year to year variability in stratospheric ozone and its loss in terms of the partial column. We selected March and October, when the significant ozone decrease occurs in most of the years, to compare partial columns for the Northern and Southern Hemisphere, respectively.

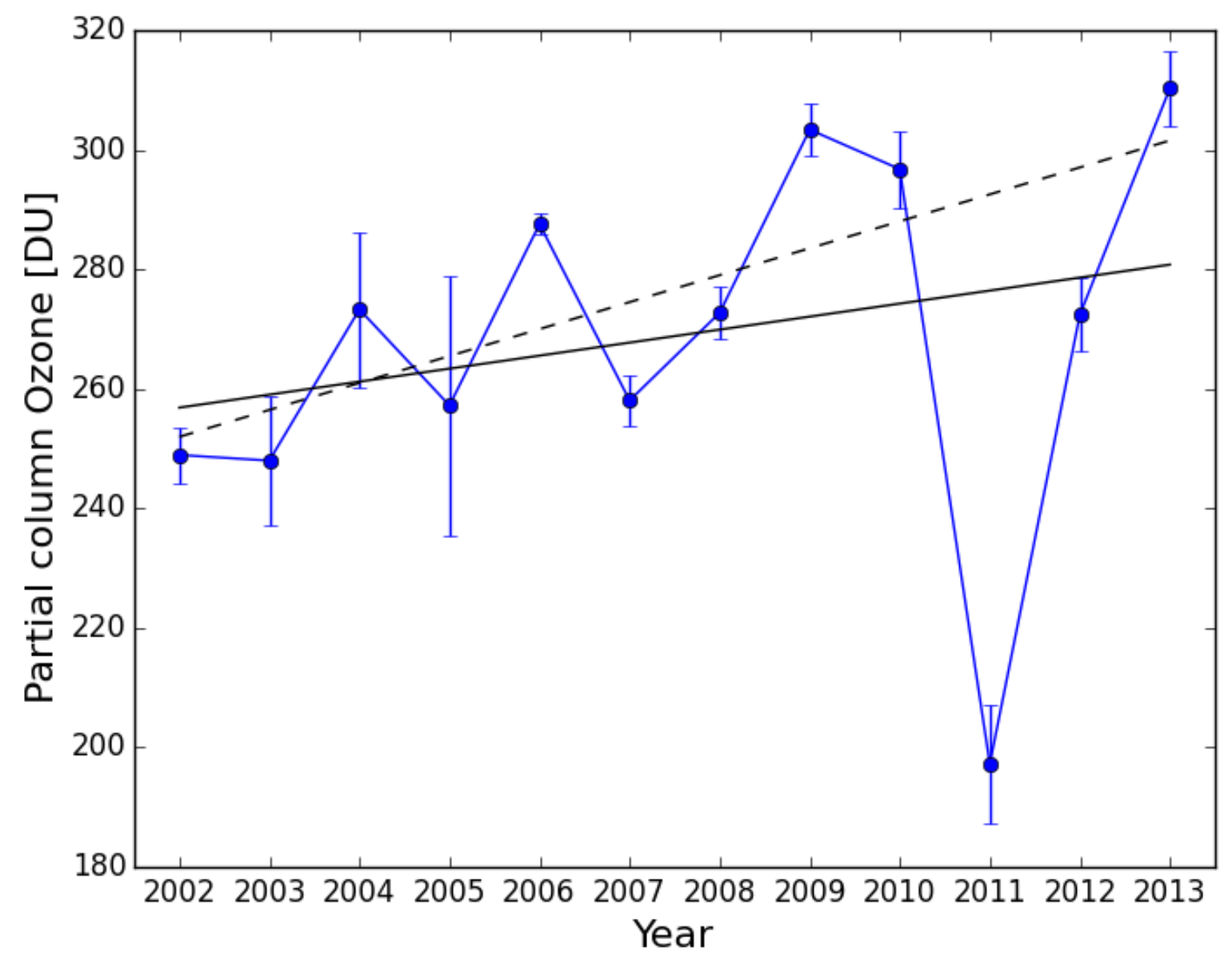

Figure 11. Monthly mean derived partial column Arctic ozone in March between 425 and $950 \mathrm{~K}$ (90-7 hPa, 15-40 km) in Dobson units (DU). The error bars indicate the standard deviation one sigma. The black solid line is a linear regression and the dashed line is also a linear regression excluding the 2011 winter.

Fig. 11 and Fig. 12 indicate the partial column of ozone and depletion in March for altitudes between $425-900 \mathrm{~K}$. The detailed values are listed in table 1. As we indicated in section 4.4.1, there is an unprecedented large ozone loss in 2011, which 5 is seen as an outlier in the stratospheric ozone column. The difference of the partial column loss for the winter of 2012/2013 
Atmos. Chem. Phys. Discuss., doi:10.5194/acp-2016-352, 2016

Manuscript under review for journal Atmos. Chem. Phys.

Published: 30 June 2016

(C) Author(s) 2016. CC-BY 3.0 License.
Atmospheric

Chemistry

and Physics

Discussions

(c) (1)

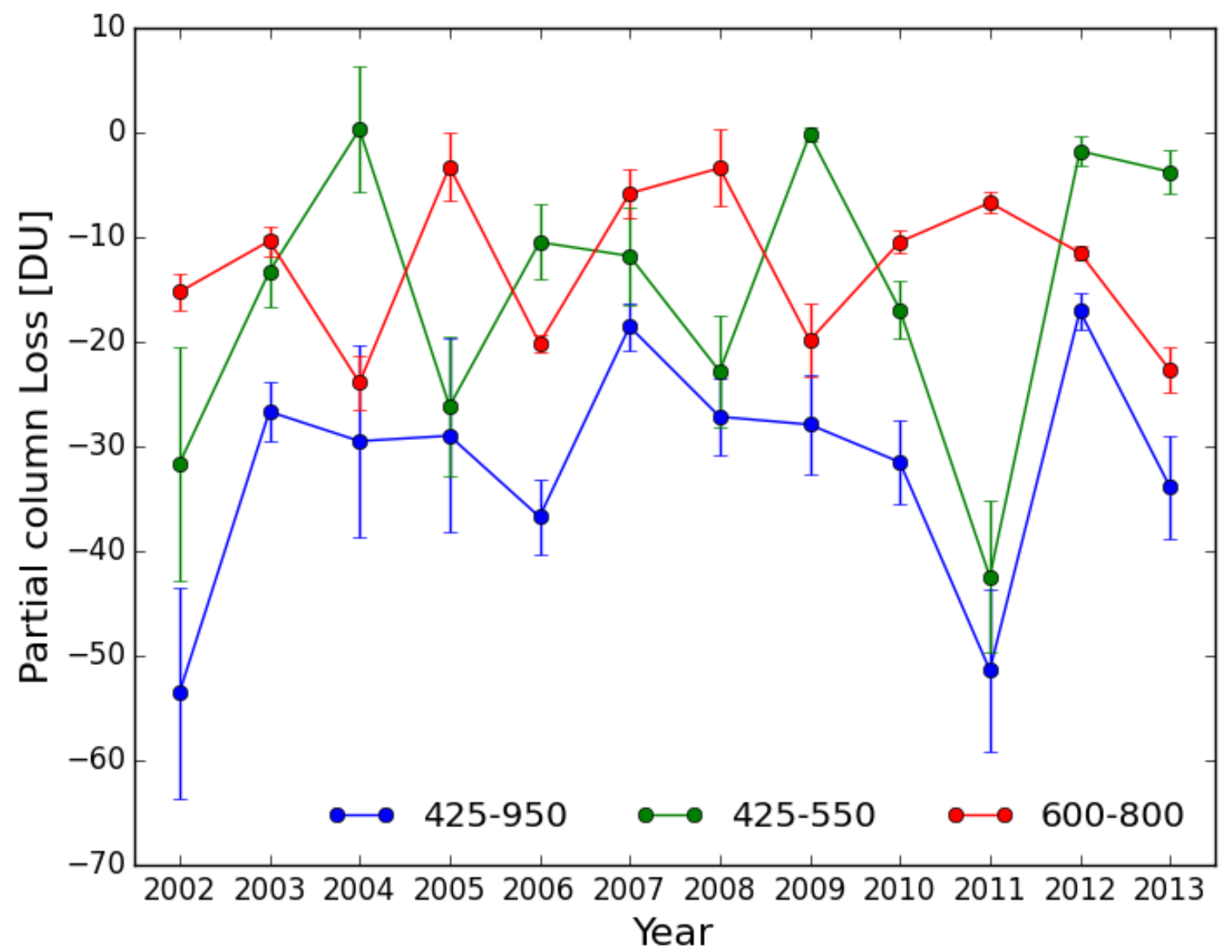

Figure 12. Monthly mean derived partial column Arctic ozone loss in March in three different layers. The green, red and blue lines correspond to the lower (potential temperature of 425-550 K, approximately below $20 \mathrm{~km}$ ), middle (600-800 K, around $30 \mathrm{~km})$ and the lower-mid stratosphere $(425-950 \mathrm{~K}, 15-40 \mathrm{~km})$, respectively. The error bars indicate the standard deviation in March for each layer.

from the linear-regression line indicated as the black solid line is approximately $60 \mathrm{DU}$, which is close to the derived column loss in March. The regression without the 2011 data point, shown as the dashed line in the figure, has a slope of 4.51 DU per year (45 DU per decade) with p-value of 0.01 (see also table 3). This increase is faster than the increase in the Southern Hemisphere of about 10 - 25 DU per decade concluded in WMO (2014). The atmospheric $\mathrm{CO}_{2}$ concentration continued to increase during the past decade IPCC (2013). According to a global circulation model experiment, increase in $\mathrm{CO}_{2}$ enhance the Brewer-Dobson circulation (BDC) in the Northern Hemisphere in the upper stratosphere much more than the in Southern

5 Hemisphere because stationary waves are more active in the upper stratosphere during winter (Kodama et al., 2007). This could be consistent with our observations of no significant increase in Southern Hemisphere ozone while we see an increase of 4.51 
Atmos. Chem. Phys. Discuss., doi:10.5194/acp-2016-352, 2016

Manuscript under review for journal Atmos. Chem. Phys.

Chemistry

Published: 30 June 2016

(c) Author(s) 2016. CC-BY 3.0 License.

Table 1. Partial column ozone and estimated ozone loss in the Arctic vortex (EQL poleward of $70^{\circ}$ ). The partial column is calculated between $425 \mathrm{~K}$ and $950 \mathrm{~K}$ using ECMWF temperature and pressure. Monthly mean of ozone and loss in March is given together with its standard deviation.

\begin{tabular}{|c|c|c|c|c|}
\hline Year & $\begin{array}{r}\text { Monthly ozone [DU] } \\
\text { in March } \\
\text { in 425-950 K }\end{array}$ & $\begin{array}{r}\text { Monthly loss [DU] } \\
\text { in March } \\
\text { in 425-950 K }\end{array}$ & Max. loss [DU] & $\begin{array}{l}\text { Max. loss date } \\
\text { YY/MM/DD } \\
\text { (Days of year) }\end{array}$ \\
\hline 2002 & $248( \pm 4)$ & $-53( \pm 10)$ & -63 & $2002 / 03 / 10(68)$ \\
\hline 2003 & $247( \pm 10)$ & $-26( \pm 2)$ & -31 & $2003 / 03 / 13(71)$ \\
\hline 2004 & $273( \pm 12)$ & $-29( \pm 9)$ & -47 & 2004/03/31 (90) \\
\hline 2005 & $257( \pm 21)$ & $-28( \pm 9)$ & -41 & 2005/03/14 (72) \\
\hline 2006 & $287( \pm 1)$ & $-36( \pm 3)$ & -42 & $2006 / 03 / 15(73)$ \\
\hline 2007 & $258( \pm 4)$ & $-18( \pm 2)$ & -23 & 2007/03/05 (63) \\
\hline 2008 & $272( \pm 4)$ & $-27( \pm 3)$ & -35 & 2008/03/31 (90) \\
\hline 2009 & $303( \pm 4)$ & $-27( \pm 4)$ & -34 & $2009 / 03 / 24(82)$ \\
\hline 2010 & $296( \pm 6)$ & $-31( \pm 4)$ & -36 & $2010 / 03 / 23(81)$ \\
\hline 2011 & $197( \pm 9)$ & $-51( \pm 7)$ & -59 & $2011 / 03 / 28(86)$ \\
\hline 2012 & $272( \pm 6)$ & $-17( \pm 1)$ & -23 & $2012 / 02 / 18(48)$ \\
\hline 2013 & $310( \pm 6)$ & $-33( \pm 4)$ & -41 & $2013 / 03 / 25(83)$ \\
\hline
\end{tabular}

DU per year in the Northern Hemisphere. In Fig. 12, the contributions of ozone loss in the lower stratosphere (425-550 K) and middle stratosphere $(600-800 \mathrm{~K})$ are also shown. We can see that the loss in 2011 is dominated by the loss in the lower stratosphere. In addition a loss of more than 20 DU loss below $550 \mathrm{~K}$ repeats every 3 years (2001/2002, 2004/2005, 2007/2008 and 2010/2011 winters), while more than 20DU losses between $600 \mathrm{~K}$ and $800 \mathrm{~K}$ are seen during winters characterised by major mid-winter SSW events (2003/2004, 2005/2006, 2008/2009 and 2012/2013). This periodicity is likely associated with dynamical processes in the stratosphere such as the QBO. However, we still have a large uncertainty in the statistics and do not

5 know why we see a loss of about 50 DU in 2002 even though it is not immediately obvious in the VMR profiles. A potential explanation is spread of ozone loss over a wider vertical range. The vortex in warmer winters is relatively weak due to SSWs and thus more inflow from outside the vortex can be expected. Another reason could be an error in the estimate of the vertical descent inside the vortex. Since the heating rate from SLIMCAT is provided every 12 hours, we linearly interpolate it in time. This produces large uncertainties in the vertical motion particularly in the complex radiative situation as the polar night comes to an end and the sun begins to heat the stratosphere. This issue generates an error of roughly \pm 0.2 ppmv in VMR and tends to under/over-estimation in the cold/warm and stable/unstable vortex.

In the Southern Hemisphere, the stratospheric ozone change from year to year behaves randomly, while the column losses 5 are more consistent except for 2002 when an unusual SSW event was observed over Antarctica (see Fig. 13 and 14 and table 2). The main driver of the inter-annual variability of the Antarctic ozone loss is the variation in meteorological processes which induce disturbances of the polar vortex (WMO, 2014). The altitude dependence in loss is clearer in the Southern Hemisphere 
Atmos. Chem. Phys. Discuss., doi:10.5194/acp-2016-352, 2016

Manuscript under review for journal Atmos. Chem. Phys.

Published: 30 June 2016

(C) Author(s) 2016. CC-BY 3.0 License.

(c) (i)
Atmospheric

Chemistry

and Physics

Discussions

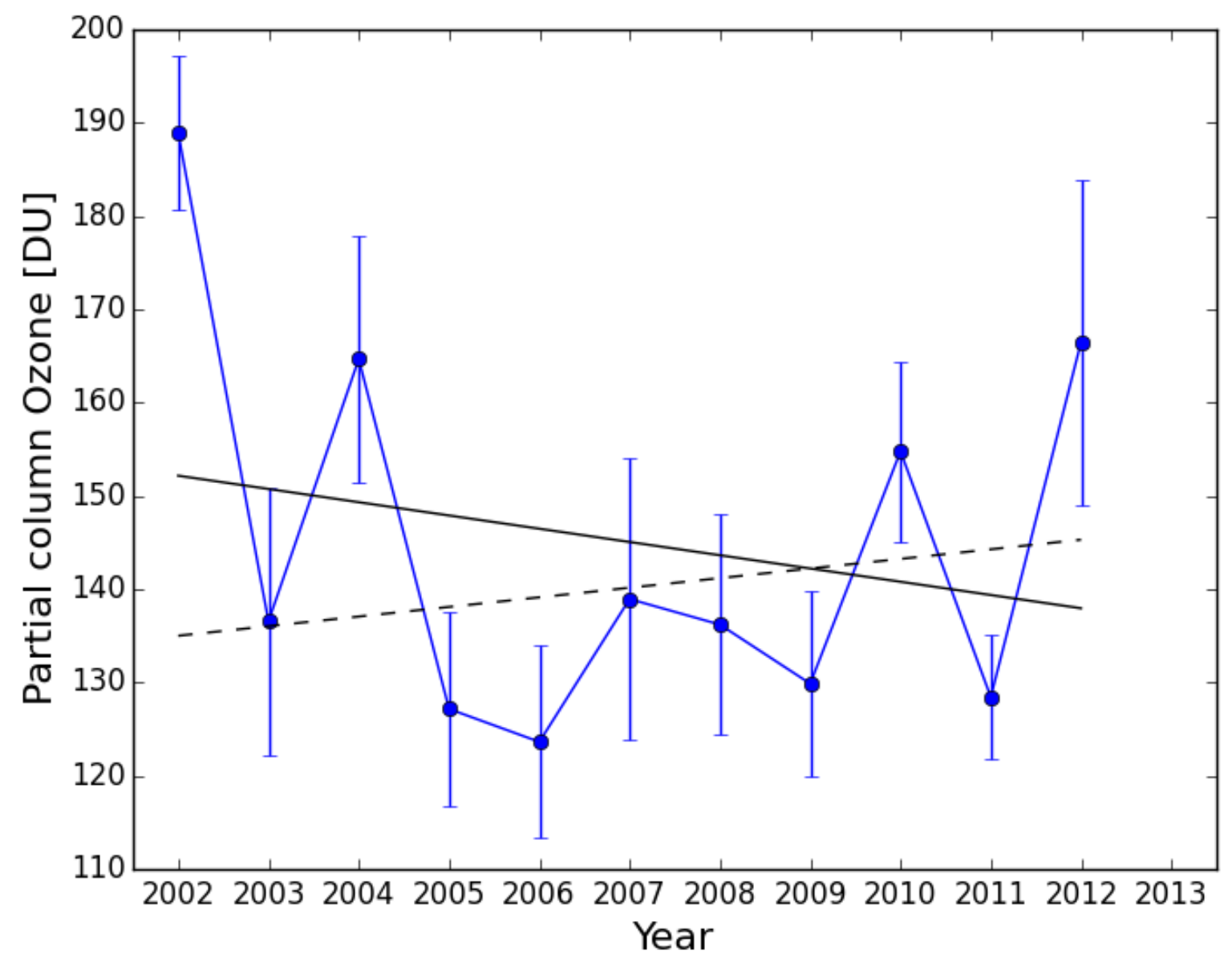

Figure 13. Monthly mean derived partial column Antarctic ozone in October between 425 and $950 \mathrm{~K}$. The black solid line is a liner regression and the dashed line is also a linear regression excluding the 2002 winter.

than in the Northern Hemisphere, i.e, the dominant loss occurs mostly below $500 \mathrm{~K}$. The regression slope makes less sense in the Southern Hemisphere because the correlation coefficients $\mathrm{r}$ are low while p-value are greater than 0.5 (Table 3 ). The calculated increase in the stratospheric ozone when excluding 2002 is 1.03 DU per year, although the statistical confidence is not high enough, and agrees with the value given by WMO (2014).

\section{Summary}

We have studied ozone loss in the Northern and Southern Hemisphere for the years between 2002 and 2013 using Odin/SMR ozone profile observations. The data assimilation technique was employed using the DIAMOND model to produce realistic 
Atmos. Chem. Phys. Discuss., doi:10.5194/acp-2016-352, 2016

Manuscript under review for journal Atmos. Chem. Phys.

Published: 30 June 2016

(C) Author(s) 2016. CC-BY 3.0 License.

\section{(c) (i)}

Atmospheric

Chemistry

and Physics

Discussions

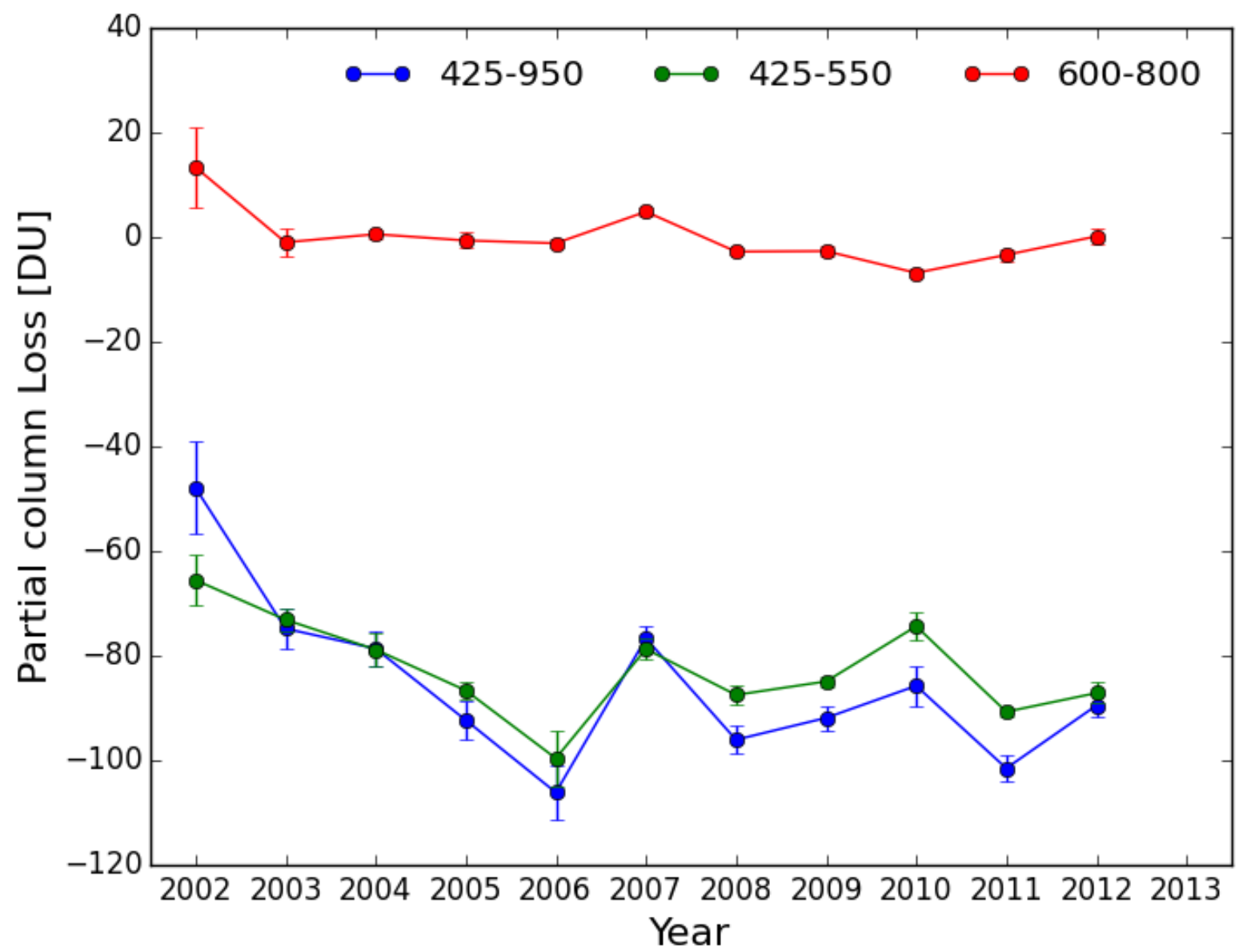

Figure 14. Same as figure 12 but for the Southern Hemisphere.

ozone fields in the low-mid stratosphere. We applied an equivalent latitude of $70^{\circ}$ as the border of the polar vortex. A vertical range of $425 \mathrm{~K}-950 \mathrm{~K}$ in the potential temperature was selected to provide active and passive ozone maps. This range covers not only the lowest stratosphere but also the middle stratosphere and is wider than other ozone loss studies for different winters.

Two different frequency modes for the SMR ozone retrieval, $501 \mathrm{GHz}$ and $544 \mathrm{GHz}$, were employed in this study. The internal comparison of the two modes shows that the active ozone fields are affected by measurement quality. Above $550 \mathrm{~K}$, active ozone derived from the two frequency modes matches to within 10\%. The largest difference occurs in the Southern Hemisphere below $550 \mathrm{~K}$ where ozone depletion occurs. $544 \mathrm{GHz}$ ozone is 0.5 ppmv lower than $501 \mathrm{GHz}$ ozone. The reason why we have such a big difference in the lowest stratosphere is a poor sensitivity in the SMR $501 \mathrm{GHz}$ measurement at this height. 
Atmos. Chem. Phys. Discuss., doi:10.5194/acp-2016-352, 2016

Manuscript under review for journal Atmos. Chem. Phys.

Published: 30 June 2016

(C) Author(s) 2016. CC-BY 3.0 License.
Atmospheric 을

Chemistry

and Physics

Discussions

Table 2. Partial column of ozone and estimated ozone hole in the Antarctic vortex (EQL poleward of $70^{\circ}$ ). The partial column is calculated between $425 \mathrm{~K}$ and $950 \mathrm{~K}$ using ECMWF temperature and pressure. Monthly mean of ozone and loss in October are given with their standard deviations.

\begin{tabular}{|c|c|c|c|c|}
\hline Year & $\begin{array}{r}\text { Monthly ozone [DU] } \\
\text { in October } \\
\text { in } 425-950 \mathrm{~K}\end{array}$ & $\begin{array}{r}\text { Monthly loss [DU] } \\
\text { in October } \\
\text { in } 425-950 \mathrm{~K}\end{array}$ & Max. loss [DU] & $\begin{array}{l}\text { Max. loss date } \\
\text { YY/MM/DD } \\
\text { (Days of year) }\end{array}$ \\
\hline 2002 & $188( \pm 8)$ & $-47( \pm 8)$ & -64 & $2002 / 09 / 23(265)$ \\
\hline 2003 & $136( \pm 14)$ & $-74( \pm 3)$ & -85 & 2003/11/01 (304) \\
\hline 2004 & $164( \pm 13)$ & $-78( \pm 3)$ & -110 & $2004 / 11 / 16(320)$ \\
\hline 2005 & $127( \pm 10)$ & $-92( \pm 3)$ & -104 & 2005/11/11 (314) \\
\hline 2006 & $123( \pm 10)$ & $-106( \pm 5)$ & -124 & 2006/11/07 (310) \\
\hline 2007 & $138( \pm 15)$ & $-76( \pm 2)$ & -113 & $2007 / 11 / 27(330)$ \\
\hline 2008 & $136( \pm 11)$ & $-96( \pm 2)$ & -147 & $2008 / 11 / 30(334)$ \\
\hline 2009 & $129( \pm 9)$ & $-91( \pm 2)$ & -113 & $2009 / 11 / 26(329)$ \\
\hline 2010 & $154( \pm 9)$ & $-85( \pm 3)$ & -134 & $2010 / 11 / 30(333)$ \\
\hline 2011 & $128( \pm 6)$ & $-101( \pm 2)$ & -113 & $2011 / 11 / 25(328)$ \\
\hline 2012 & $166( \pm 17)$ & $-89( \pm 2)$ & -104 & $2012 / 11 / 11(315)$ \\
\hline
\end{tabular}

Our estimation of the vortex mean ozone loss largely agrees with other studies within $\pm 0.3 \mathrm{ppmv}$, while there are some discrepancies due to the differences in methods or instruments and the vortex edge criteria (Sonkaew et al., 2013; Kuttippurath et al., 2015). $544 \mathrm{GHz}$ ozone loss in the Arctic 2004/2005 winter shows good agreement with ozone loss derived from SCIAMACHY measurements by Sonkaew et al. (2013) below $450 \mathrm{~K}$ with $0.2 \mathrm{ppmv}$, while we do not see any loss around $550 \mathrm{~K}$ even if Sonkaew et al. (2013) estimated an $0.5 \mathrm{ppmv}$ loss. This fact can be explained by the different vertical resolutions of approximately $1.7 \mathrm{~km}$ in SMR $544 \mathrm{GHz}$ ozone and $3 \mathrm{~km}$ in SCIAMACHY ozone. In the comparison of Antarctic ozone depletions with Kuttippurath et al. (2015), our results agreed with MLS ozone loss within 0.1 ppmv, while were constantly 0.3 ppmv lower than their Mimosa-Chim model calculations. In Kuttippurath et al. (2015), the difference between MLS and Mimosa-Chim was due to underestimating descent in the model.

Table 3. Statistical information on the least square linear regression in Fig. 11 and 13. A r-value is a correlation coefficient. A p-value is a probability of finding a more extreme result when the null hypothesis is true.

\begin{tabular}{lcccc} 
Winters & slope [DU/year] & r-value [-] & p-value [-] & std. error [DU] \\
\hline Arctic & 2.18 & 0.26 & 0.42 & 2.59 \\
Arctic (without 2011) & 4.51 & 0.75 & 0.01 & 1.33 \\
Antarctic & -1.42 & -0.23 & 0.50 & 2.04 \\
Antarctic (without 2002) & 1.03 & 0.20 & 0.58 & 1.80
\end{tabular}


Atmos. Chem. Phys. Discuss., doi:10.5194/acp-2016-352, 2016

Manuscript under review for journal Atmos. Chem. Phys.

Published: 30 June 2016

(C) Author(s) 2016. CC-BY 3.0 License.
Atmospheric

Chemistry

and Physics

Discussions

(c) (i)

In the Northern Hemisphere, the chemical ozone loss has large inter-annual variability. Losses can be categorized in three types, which are "cold winter", "warm winter" and intermediate between cold and warm. The characteristic difference between cold and warm winters appears in the altitudes having maximum depletion. The maximum depletion in cold winters took place in the lower stratosphere below $500 \mathrm{~K}$ as for the Antarctic ozone hole. For example, in 2010/2011, when the very cold temperatures continued until the end of polar winter and made the vortex stable, the loss reached VMR values of 2.1 ppmv at $450 \mathrm{~K}$ at the end of March. The particularity of 2011 winter is more clearly seen in the partial column of ozone. In warm winters such as 2003/2004, 2005/2006, 2008/2009 and 2012/2013, losses of more than 1.5 ppmv with the peak at around $700 \mathrm{~K}$ were seen. These losses were consistent with the occurrence of major SSW events. The horizontal transport of $\mathrm{NO}_{x}$ related to the SSW is the main cause of this enhanced loss. A detailed study is in progress to access the characteristics of the two mechanisms causing ozone loss at different altitudes in cold and warm Arctic winters. The Arctic low-mid stratospheric ozone increases with 20-45 DU/decade (including and excluding loss in 2010/2011 winter respectively). However it is still difficult to give concrete evidence of ozone recovery due to the uncertainties in this estimate.

In the Southern Hemisphere during the 2002-2012 period, the Antarctic ozone hole continues to occur each springtime. Generally ozone loss starts in mid-August and becomes 2.5 ppmv below $450 \mathrm{~K}$ in October (DOY of 270-300). However the loss in Antarctic winter 2002 estimated in this study is approximately 0.5 ppmv less than Antarctic ozone depletions in other years and is due to the unstable vortex caused by a SSW. A small increase of about 10 DU/decade in Antarctic partial column ozone covering potential temperatures between $425 \mathrm{~K}$ and $950 \mathrm{~K}(15 \mathrm{~km} \sim 40 \mathrm{~km})$ since 2003 can be observed. However it is not based on strong statistical evidence.

Acknowledgements. Odin is a Swedish-led satellite project funded jointly by the Swedish National Space Board (SNSB), the Canadian European Space Agency (ESA). We thank the study group on the added-value of chemical data assimilation in the stratosphere and uppertroposphere supported by the International Space Science Institute (ISSI). We thank Martyn Chipperfield and Wuhu Feng in the University of Leeds for providing the diabatic heating rates for this study. 
Atmos. Chem. Phys. Discuss., doi:10.5194/acp-2016-352, 2016

Atmospheric

Chemistry

Manuscript under review for journal Atmos. Chem. Phys.

Published: 30 June 2016

(c) Author(s) 2016. CC-BY 3.0 License.

and Physics

Discussions

(c) (i)

\section{References}

Arnone, E., Castelli, E., Papandrea, E., Carlotti, M., and Dinelli, B. M.: Extreme ozone depletion in the 2010-2011 Arctic winter stratosphere as observed by MIPAS/ENVISAT using a 2-D tomographic approach, Atmos. Chem. Phys., 12, 9149-9165, doi:10.5194/acp-12-91492012, http://www.atmos-chem-phys.net/12/9149/2012/, 2012.

Austin, J., Butchart, N., and Shine, K. P.: Possibility of an Arctic ozone hole in a doubled- $\backslash$ rm\{CO_2\} climate., Nature, 360, 221-225, http://dx.doi.org/10.1038/360221a0, 1992.

Eichmann, K. U., Weber, M., Bramstedt, K., and Burrows, J. P.: Ozone depletion in Northern Hemisphere winter/spring 1999/2000 as measured by the Global Ozone Monitoring Experiment on ERS-2, J. Geophys. Res., 107, 8280, doi:10.1029/2001JD001148, http://dx. doi.org/10.1029/2001JD001148, 2002.

El Amraoui, L., Semane, N., Peuch, V. H., and Santee, M. L.: Investigation of dynamical processes in the polar stratospheric vortex during the unusually cold winter 2004/2005, Geophys. Res. Lett., 35, L03 803, doi:10.1029/2007GL031251, http://dx.doi.org/10.1029/ 2007GL031251, 2008.

Froidevaux, L., Jiang, Y. B., Lambert, A., Livesey, N. J., Read, W. G., Waters, J. W., Browell, E. V., Hair, J. W., Avery, M. A., McGee, T. J., Twigg, L. W., Sumnicht, G. K., Jucks, K. W., Margitan, J. J., Sen, B., Stachnik, R. A., Toon, G. C., Bernath, P. F., Boone, C. D., Walker, K. A., Filipiak, M. J., Harwood, R. S., Fuller, R. A., Manney, G. L., Schwartz, M. J., Daffer, W. H., Drouin, B. J., Cofield, R. E., Cuddy, D. T., Jarnot, R. F., Knosp, B. W., Perun, V. S., Snyder, W. V., Stek, P. C., Thurstans, R. P., and Wagner, P. A.: Validation of Aura Microwave Limb Sounder stratospheric ozone measurements, J. Geophys. Res., 113, D15S20, doi:10.1029/2007JD008771, http: //onlinelibrary.wiley.com/doi/10.1029/2007JD008771/full, 2008.

Fytterer, T., Mlynczak, M. G., Nieder, H., Pérot, K., Sinnhuber, M., Stiller, G., and Urban, J.: Energetic particle induced intra-seasonal variability of ozone inside the Antarctic polar vortex observed in satellite data, Atmos. Chem. Phys., 15, 3327-3338, doi:10.5194/acp-153327-2015, http://www.atmos-chem-phys.net/15/3327/2015/acp-15-3327-2015.html, 2015.

Grooß, J. U. and Müller, R.: The impact of mid-latitude intrusions into the polar vortex on ozone loss estimates, Atmos. Chem. Phys., 3, 395-402, doi:10.5194/acp-3-395-2003, http://www.atmos-chem-phys.net/3/395/2003/, 2003.

Grooß, J. U. and Müller, R.: Simulation of ozone loss in Arctic winter 2004/2005, Geophys. Res. Lett., 34, L05804, doi:10.1029/2006GL028901, http://dx.doi.org/10.1029/2006GL028901, 2007.

Hommel, R., Eichmann, K. U., Aschmann, J., Bramstedt, K., Weber, M., von Savigny, C., Richter, A., Rozanov, A., Wittrock, F., Khosrawi, F., Bauer, R., and Burrows, J. P.: Chemical ozone loss and ozone mini-hole event during the Arctic winter 2010/2011 as observed by SCIAMACHY and GOME-2, Atmos. Chem. Phys., 14, 3247-3276, doi:10.5194/acp-14-3247-2014, http://www.atmos-chem-phys.net/ 14/3247/2014/, 2014.

IPCC: Working Group I Contribution to the IPCC Fifth Assessment Report, Climate Change 2013: The Physical Science Basis, IPCC, AR5, $2014,2013$.

Jackson, D. R. and Orsolini, Y. J.: Estimation of Arctic ozone loss in winter 2004/05 based on assimilation of EOS MLS and SBUV/2 observations, Q. J. Roy. Meteor. Soc., 134, 1833-1841, doi:10.1002/qj.316, http://dx.doi.org/10.1002/qj.316, 2008.

Jin, J. J., Semeniuk, K., Manney, G. L., Jonsson, A. I., Beagley, S. R., McConnell, J. C., Dufour, G., Nassar, R., Boone, C. D., Walker, K. A., Bernath, P. F., and Rinsland, C. P.: Severe Arctic ozone loss in the winter 2004/2005: observations from ACE-FTS, Geophys. Res. Lett., 33, L15 801, doi:10.1029/2006GL026752, http://dx.doi.org/10.1029/2006GL026752, 2006. 
Atmos. Chem. Phys. Discuss., doi:10.5194/acp-2016-352, 2016

Atmospheric

Chemistry

Published: 30 June 2016

(c) Author(s) 2016. CC-BY 3.0 License.

and Physics

Discussions

(c) $\underset{\mathrm{Br}}{\mathrm{i}}$

Jones, A., Murtagh, D., Urban, J., Eriksson, P., and Rosevall, J.: Intercomparison of Odin/SMR ozone measurements with MIPAS and balloonsonde data, Can. J. Phys., 85, 1111-1123, http://www.ingentaconnect.com/content/nrc/cjp/2007/00000085/00000011/art00003, 2007.

Kodama, C., Iwasaki, T., Shibata, K., and Yukimoto, S.: Changes in the stratospheric mean meridional circulation due to increased CO 2 : Radiation- and sea surface temperature-induced effects, J. Geophys. Res., 112, D16 103, doi:10.1029/2006JD008219, http://onlinelibrary. wiley.com/doi/10.1029/2006JD008219/full, 2007.

Konopka, P., Engel, A., Funke, B., Müller, R., Grooß, J.-U., Günther, G., Wetter, T., Stiller, G., von Clarmann, T., Glatthor, N., Oelhaf, H., Wetzel, G., López-Puertas, M., Pirre, M., Huret, N., and Riese, M.: Ozone loss driven by nitrogen oxides and triggered by stratospheric warmings can outweigh the effect of halogens, J. Geophys. Res., 112, D05 105, doi:10.1029/2006JD007064, http://dx.doi.org/10.1029/ 2006JD007064, 2007.

Kuttippurath, J., Godin-Beekmann, S., Lefèvre, F., and Pazmiño, A.: Ozone depletion in the Arctic winter 2007-2008, Int. J. Remote Sens., 30, 4071-4082, doi:10.1080/01431160902821965, http://dx.doi.org/10.1080/01431160902821965, 2009.

Kuttippurath, J., Godin-Beekmann, S., Lefèvre, F., and Goutail, F.: Spatial, temporal, and vertical variability of polar stratospheric ozone loss in the Arctic winters 2004/2005-2009/2010, Atmos. Chem. Phys., 10, 9915-9930, doi:10.5194/acp-10-9915-2010, http: //www.atmos-chem-phys.net/10/9915/2010/, 2010.

Kuttippurath, J., Godin-Beekmann, S., Lefèvre, F., Santee, M. L., Froidevaux, L., and Hauchecorne, A.: Variability in Antarctic ozone loss in the last decade (2004-2013): high-resolution simulations compared to Aura MLS observations, Atmos. Chem. Phys., 15, 10385-10397, doi:10.5194/acp-15-10385-2015, http://www.atmos-chem-phys.net/15/10385/2015/acp-15-10385-2015.html, 2015.

Lahoz, W., Khattatov, B., and Ménard, R.: Data assimilation: Making sense of observations, Springer Berlin Heidelberg, 2010.

Lait, L. R.: An Alternative Form for Potential Vorticity, J. Atmos. Sci., 51, 1754-1759, doi:10.1175/15200469(1994)051<1754:AAFFPV>2.0.CO;2, http://dx.doi.org/10.1175/1520-0469(1994)051<1754:AAFFPV>2.0.CO;2, 1994.

Manney, G. L., Santee, M. L., Froidevaux, L., Hoppel, K., Livesey, N. J., and Waters, J. W.: No Title, Geophys. Res. Lett., 33 , L04 802, 2006.

Manney, G. L., Santee, M. L., Rex, M., Livesey, N. J., Pitts, M. C., Veefkind, P., Nash, E. R., Wohltmann, I., Lehmann, R., Froidevaux, L., Poole, L. R., Schoeberl, M. R., Haffner, D. P., Davies, J., Dorokhov, V., Gernandt, H., Johnson, B., Kivi, R., Kyro, E., Larsen, N., Levelt, P. F., Makshtas, A., McElroy, C. T., Nakajima, H., Parrondo, M. C., Tarasick, D. W., von der Gathen, P., Walker, K. A., and Zinoviev, N. S.: Unprecedented Arctic ozone loss in 2011, Nature, 478, 469-475, http://dx.doi.org/10.1038/nature10556, 2011.

Murtagh, D., Frisk, U., Merino, F., Ridal, M., Jonsson, A., Stegman, J., Witt, G., Eriksson, P., Jiménez, C., Megie, G., de la Noë, J., Ricaud, P., Baron, P., Pardo, J. R., Hauchcorne, A., Llewellyn, E. J., Degenstein, D. A., Gattinger, R. L., Lloyd, N. D., Evans, W. F. J., McDade, I. C., Haley, C. S., Sioris, C., von Savigny, C., Solheim, B. H., McConnell, J. C., Strong, K., Richardson, E. H., Leppelmeier, G. W., Kyrölä, E., Auvinen, H., and Oikarinen, L.: An overview of the Odin atmospheric mission, Can. J. Phys., 80, 309-319, doi:10.1139/p01-157, http://dx.doi.org/10.1139/p01-157, 2002.

Nash, E. R., Newman, P. A., Rosenfield, J. E., and Schoeberl, M. R.: An objective determination of the polar vortex using Ertel's potential vorticity, J. Geophys. Res., 101, 9471-9478, doi:10.1029/96JD00066, http://dx.doi.org/10.1029/96JD00066, 1996.

Osterman, G. B., Salawitch, R. J., Sen, B., Toon, G. C., Stachnik, R. A., Pickett, H. M., Margitan, J. J., Blavier, J.-F., and Peterson, D. B.: Balloon-borne measurements of stratospheric radicals and their precursors: Implications for the production and loss of ozone, Geophys. Res. Lett., 24, 1107-1110, doi:10.1029/97GL00921, http://dx.doi.org/10.1029/97GL00921, 1997.

Prather, M. J.: Numerical Advection by Conservation of Second-Order Moments, J. Geophys. Res., 91, 6671-6681, doi:10.1029/JD091iD06p06671, http://dx.doi.org/10.1029/JD091iD06p06671, 1986. 
Atmos. Chem. Phys. Discuss., doi:10.5194/acp-2016-352, 2016

Manuscript under review for journal Atmos. Chem. Phys.

Published: 30 June 2016

(c) Author(s) 2016. CC-BY 3.0 License.
Atmospheric

Chemistry

and Physics

Discussions

(c) (1)

Rex, M., Salawitch, R. J., Deckelmann, H., von der Gathen, P., Harris, N. R. P., Chipperfield, M. P., Naujokat, B., Reimer, E., Allaart, M., Andersen, S. B., Bevilacqua, R., Braathen, G. O., Claude, H., Davies, J., De Backer, H., Dier, H., Dorokhov, V., Fast, H., Gerding, M., Godin-Beekmann, S., Hoppel, K., Johnson, B., Kyrö, E., Litynska, Z., Moore, D., Nakane, H., Parrondo, M. C., Risley, A. D., Skrivankova, P., Stübi, R., Viatte, P., Yushkov, V., and Zerefos, C.: Arctic winter 2005: Implications for stratospheric ozone loss and climate change, Geophys. Res. Lett., 33, L23 808, doi:10.1029/2006GL026731, http://dx.doi.org/10.1029/2006GL026731, 2006.

Rosenfield, J. E., Newman, P. A., and Schoeberl, M. R.: Computations of diabatic descent in the stratospheric polar vortex, Geophys. Res. : Atmospheres, 99, 16677-16689, doi:10.1029/94JD01156, http://dx.doi.org/10.1029/94JD01156, 1994.

Rösevall, J. D., Murtagh, D. P., and Urban, J.: Ozone depletion in the 2006/2007 Arctic winter, Geophys. Res. Lett., 34, L21 809, doi:10.1029/2007GL030620, http://dx.doi.org/10.1029/2007GL030620, 2007.

Rösevall, J. D., Murtagh, D. P., Urban, J., Feng, W., Eriksson, P., and Brohede, S.: A study of ozone depletion in the 2004/2005 Arctic winter based on data from Odin/SMR and Aura/MLS, J. Geophys. Res., 113, D13 301, doi:10.1029/2007JD009560, http://dx.doi.org/10.1029/ 2007JD009560, 2008.

Sagi, K., Murtagh, D., Urban, J., Sagawa, H., and Kasai, Y.: The use of SMILES data to study ozone loss in the Arctic winter 2009/2010 and comparison with Odin/SMR data using assimilation techniques, Atmos. Chem. Phys., 14, 1285512 869, doi:10.5194/acp-14-12855-2014, http://www.atmos-chem-phys.net/14/12855/2014/http://www.atmos-chem-phys.net/14/12855/ 2014/acp-14-12855-2014.pdf, 2014.

Shindell, D. T., Rind, D., and Lonergan, P.: Increased polar stratospheric ozone losses and delayed eventual recovery owing to increasing greenhouse-gas concentrations., Nature, 392, 589-592, http://dx.doi.org/10.1038/33385, 1998.

Singleton, C. S., Randall, C. E., Harvey, V. L., Chipperfield, M. P., Feng, W., Manney, G. L., Froidevaux, L., Boone, C. D., Bernath, P. F., Walker, K. A., McElroy, C. T., and Hoppel, K. W.: Quantifying Arctic ozone loss during the 2004-2005 winter using satellite observations and a chemical transport model, J. Geophys. Res., 112, D07 304, doi:10.1029/2006JD007463, http://dx.doi.org/10.1029/2006JD007463, 2007.

Sinnhuber, B. M., Stiller, G., Ruhnke, R., von Clarmann, T., Kellmann, S., and Aschmann, J.: Arctic winter 2010/2011 at the brink of an ozone hole, Geophys. Res. Lett., 38, L24 814, doi:10.1029/2011GL049784, http://dx.doi.org/10.1029/2011GL049784, 2011.

Sonkaew, T., von Savigny, C., Eichmann, K.-U., Weber, M., Rozanov, A., Bovensmann, H., Burrows, J. P., and Grooß, J.-U.: Chemical ozone losses in Arctic and Antarctic polar winter/spring season derived from SCIAMACHY limb measurements 2002-2009, Atmos. Chem. Phys., 13, 1809-1835, doi:10.5194/acp-13-1809-2013, http://www.atmos-chem-phys.net/13/1809/2013/acp-13-1809-2013-relations. html, 2013.

Tilmes, S., Müller, R., Grooß, J. U., and Russell III, J. M.: Ozone loss and chlorine activation in the Arctic winters 1991-2003 derived with the tracer-tracer correlations, Atmos. Chem. Phys., 4, 2181-2213, doi:10.5194/acp-4-2181-2004, http://www.atmos-chem-phys.net/ 4/2181/2004/, 2004.

Tilmes, S., Müller, R., Grooß, J.-U., Spang, R., Sugita, T., Nakajima, H., and Sasano, Y.: Chemical ozone loss and related processes in the Antarctic winter 2003 based on Improved Limb Atmospheric Spectrometer (ILAS)-II observations, J. Geophys. Res., 111, D11S12, doi:10.1029/2005JD006260, http://dx.doi.org/10.1029/2005JD006260, 2006.

Tsvetkova, N. D., Yushkov, V. A., Luk'yanov, A. N., Dorokhov, V. M., and Nakane, H.: Record-breaking chemical destruction of ozone in the arctic during the winter of 2004/2005, Izvestiya, Atmospheric and Oceanic Physics, 43, 592-598, doi:10.1134/S0001433807050076, http://dx.doi.org/10.1134/S0001433807050076, 2007. 
Atmos. Chem. Phys. Discuss., doi:10.5194/acp-2016-352, 2016

Manuscript under review for journal Atmos. Chem. Phys.

Published: 30 June 2016

(c) Author(s) 2016. CC-BY 3.0 License.

(c) (1)
Atmospheric

Chemistry

and Physics

Discussions

480 Urban, J., Lautié, N., Le Flochmoën, E., Jiménez, C., Eriksson, P., de La Noë, J., Dupuy, E., Ekström, M., El Amraoui, L., Frisk, U., Murtagh, D., Olberg, M., and Ricaud, P.: Odin/SMR limb observations of stratospheric trace gases: Level 2 processing of ClO, N2O, HNO3, and O3, J. Geophys. Res., 110, D14 307, doi:10.1029/2004JD005741, http://dx.doi.org/10.1029/2004JD005741, 2005.

WMO: Scientific Assessment of Ozone Depletion: 2010, Global Ozone Research and Monitoring Project-Report No. 52, 516pp., Geneva, Switzerland, 2011.

WMO: Scientific Assessment of Ozone Depletion: 2014, Global Ozone Research and Monitoring Project-Report No. 55, 416 pp., Geneva, Switzerland, 2014.

Wohltmann, I., Wegner, T., Müller, R., Lehmann, R., Rex, M., Manney, G. L., Santee, M. L., Bernath, P., Sumi \'nska-Ebersoldt, O., Stroh, F., von Hobe, M., Volk, C. M., Hösen, E., Ravegnani, F., Ulanovsky, A., and Yushkov, V.: Uncertainties in modelling heterogeneous chemistry and Arctic ozone depletion in the winter 2009/2010, Atmos. Chem. Phys., 13, 3909-3929, doi:10.5194/acp-13-3909-2013, http://www.atmos-chem-phys.net/13/3909/2013/, 2013. 